\title{
Flood Consequences of Land-Use Changes at a Ski Resort: Overcoming a Geomorphological Threshold (Portainé, Eastern Pyrenees, Iberian Peninsula)
}

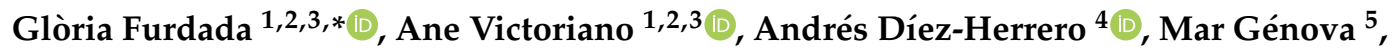

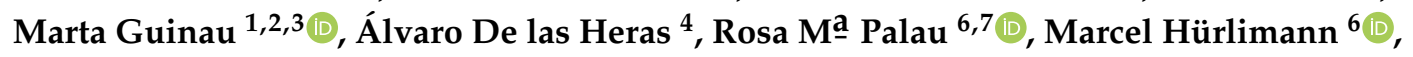 \\ Giorgi Khazaradze ${ }^{1,2,3}{ }^{\mathbb{D}}$, Josep Maria Casas ${ }^{1,3}$, Aina Margalef ${ }^{8}$, Jordi Pinyol ${ }^{9}$ and \\ Marta González 9 (D) \\ 1 Department of Earth and Ocean Dynamics, Faculty of Earth Sciences, University of Barcelona, c/ Martí i \\ Franquès s/n, 08028 Barcelona, Spain; ane3790@gmail.com (A.V.); mguinau@ub.edu (M.G.); \\ gkhazar@ub.edu (G.K.); casas@ub.edu (J.M.C.) \\ 2 RISKNAT Research Group, University of Barcelona, c/ Martí i Franquès s/n, 08028 Barcelona, Spain \\ 3 Geomodels Research Institute, University of Barcelona, c/ Martí i Franquès s/n, 08028 Barcelona, Spain \\ 4 Geological Hazards Division, Geological Survey of Spain \& IMDEA-Water. c/ Ríos Rosas 23, \\ 28003 Madrid, Spain; andres.diez@igme.es (A.D.-H.); alvarodelasheras@hotmail.com (Á.D.1.H.) \\ 5 Department of Natural Systems and Resources, Technical University of Madrid (UPM), 28040 Madrid, Spain; \\ mar.genova@upm.es \\ 6 Department of Civil and Environmental Engineering, Division of Geotechnical Engineering and Geosciences, \\ UPC BarcelonaTECH, c/ Jordi Girona 1-3 (D2), 08034 Barcelona, Spain; rosa.m.palau@upc.edu (R.M.P.); \\ marcel.hurlimann@upc.edu (M.H.) \\ 7 Center of Applied Research in Hydrometeorology, Universitat Politècnica de Catalunya, BarcelonaTech, \\ c/ Jordi Girona 1-3 (C4), 08034 Barcelona, Spain \\ 8 Centre d'Estudis de la Neu I la Muntanya d'Andorra/Snow and Mountain Research Center of Andorra, Av. \\ Rocafort 21-23, Edifici Molí 3r pis, AD600 Sant Julià de Lòria, Andorra; amargalef@iea.ad \\ 9 Group of the Geological Hazard Prevention Map of Catalonia, Cartographic and Geological Institute of \\ Catalonia, Parc de Montjuïc S/N, 08038 Barcelona, Spain; Jordi.Pinyol@icgc.cat (J.P.); \\ Marta.Gonzalez@icgc.cat (M.G.) \\ * Correspondence: gloria.furdada@ub.edu; Tel.: +34-93-402-1370
}

Received: 24 December 2019; Accepted: 25 January 2020; Published: 29 January 2020

\begin{abstract}
The sensitive mountain catchment of Portainé (Eastern Pyrenees, Iberian Peninsula) has recently experienced a significant change in its torrential dynamics due to human disturbances. The emplacement of a ski resort at the headwaters led to the surpassing of a geomorphological threshold, with important consequences during flood events. Consequently, since 2008, channel dynamics have turned into sediment-laden, highly destructive torrential flows. In order to assess this phenomenon and o acquire a holistic understanding of the catchment's behaviour, we carried out a field work-based multidisciplinary study. We considered the interaction of the various controlling factors, including bedrock geology, geomorphological evolution, derived soils and coluvial deposits, rainfall patterns, and the hydrological response of the catchment to flood events. Moreover, anthropogenic land-use changes, its consequential hydrogeomorphic effects and the role of vegetation were also taken into account. Robust sedimentological and geomorphological evidence of ancient dense debris flows show that the basin has shifted around this threshold, giving rise to two different behaviours or equilibrium conditions throughout its history: alternating periods of moderate, bedload-laden flows and periods of high sediment-laden debris flow dynamics. This shifting could have extended through the Holocene. Finally, we discuss the possible impact of climate and global change, as the projected effects suggest future soil and forest degradation; this, jointly with more intense rainfalls in these mountain environments, would exacerbate the future occurrence of dense sediment-laden flows at Portainé, but also in other nearby, similar basins.
\end{abstract}


Keywords: flood torrential dynamics; geomorphological threshold; land-use changes; ski resort; hydrological response; Pyrenees

\section{Introduction}

\subsection{The Geomorphological Threshold Concept}

The International Association of Geomorphologists, in its glossary compiled by Goudie [1], defines geomorphological threshold as "a threshold of landform stability that is exceeded either by intrinsic change of the landform itself, or by a progressive change of an external variable". This definition derives from the remarkable ideas of [2-5], among others, also compiled and discussed by [6]. Gregory [7] defines thresholds as stages or tipping points at which essential characteristics change dramatically. They are boundary conditions separating two distinct phases or equilibria conditions. According to [8], equilibrium typically refers to a condition with no net change and is thus very dependent on the time span being considered. Thus, the dynamic equilibrium concept assumes that, in a basin, forms and processes adjust to convey water and sediment supply while maintaining a balance with the erosional resistance and the stability characteristics of the banks $[9,10]$. If there is a change in the balance of forces that control the state of the system, it may become unstable, a threshold can be overpassed, and it can shift from a state of dynamic equilibrium to another state. The last book chapters from [5], dedicated to thresholds and man, emphasize how human activities can lead to overpass thresholds and modify geomorphic processes, such as accelerating erosion [11].

The hypothesis that a geomorphological threshold was exceeded because of anthropogenically induced land cover changes can be applied very well to the mountain basin of Portainé (eastern Pyrenees, Iberian Peninsula; see Section 1.2 and Figure 1). In response to an ordinary rainfall event in 2008 , the torrential dynamics turned dramatically into heavily sediment laden, destructive flows (Section 1.4).

Gregory [7] considers that a holistic view acknowledges the need to understand how a land surface system operates, as well as to know the relation of its component parts. In Portainé, the dynamics reveal a complex connectivity among water-soil-rock processes. Specialised research, only focused on geomorphology, hydrology, or flow dynamics, does not capture the complexity of the processes in this mountain environment. Thus, the problem should not be considered exclusively by a single discipline, but in the wider context, by looking at relationships as a whole. Consequently, our approach is based on our previous, specifically focussed works carried out with different methods and with conclusive proofs and results [12-22] and also considers the complexity of the system as suggested by Kondolf and Piégay [23], by working with the convergence of evidence. From this scope, this paper integrates and synthesizes the results of multidisciplinary research carried out in the basin of Portainé, as only through this holistic approach can the hypothetical surpassing of the geomorphic threshold after flood events be detected and characterized. 


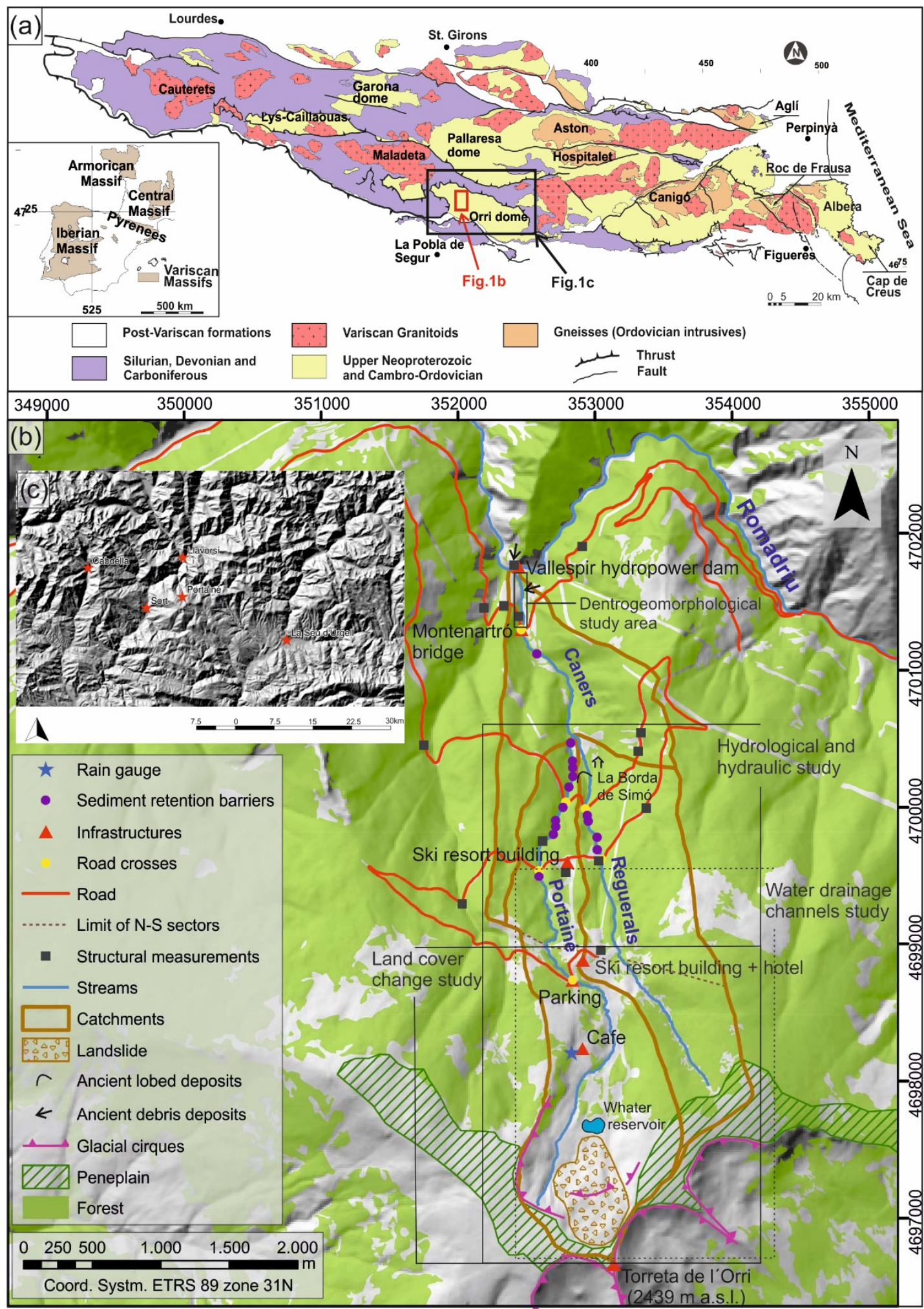

Figure 1. Study area: (a) Geographic and geological location of the Axial Pyrenees; Pre-Variscan materials, on which the study area is located, stand out. (b) Geomorphological setting and delineation of the Portainé drainage basin, including sub-areas of the study; specific location of studied sediments and anthropogenically significant elements cited throughout the article. (c) Locations of the rain gauges used in this study. 


\subsection{Study Area}

The Portainé basin (Figure 1) $\left(5.7 \mathrm{~km}^{2}\right)$ is located in the Pyrenees (Pallars Sobirà County, Catalonia, Spain), with elevations ranging from $2439 \mathrm{~m}$ a.s.l. (Torreta de l'Orri peak) to $950 \mathrm{~m}$ a.s.l. (Romadriu river and Vallespir hydropower dam). It includes the Portainé mountain torrent, its tributary Reguerals and, downstream, their confluence (at $1285 \mathrm{~m}$ a.s.l.), the lower reach named Caners (4.3, 3 and $1.5 \mathrm{~km}$ long; $25.2 \%, 31.3 \%$ and $23.1 \%$ average gradient, respectively). The ski resort of Port Ainé was set up at the headwaters and was inaugurated in 1986; its access road follows the hillslopes, repeatedly crossing the channels.

In this region, as the altitude increases, the montane forests are dominated first by Quercus pubescens Willd (and less frequently by Quercus petraea (Mattuschka) Liebl), second by Pinus sylvestris, which is sometimes mixed with Abies alba Miller and, in the subalpine belt, by Pinus uncinata Ramond ex DC. With respect to soil moisture conditions in ravines and rivers, Fraxinus excelsior L. forests and mixed deciduous forests with Tilia platyphyllos Scop and Corylus avellane L. are developed [24]. There are some bushes and herbaceous crops at medium altitudes and, from $2100 \mathrm{~m}$ upwards, there are pastures with patches of Rhododendron ferrugineum L. bushes.

The climate is Alpine Mediterranean, strongly influenced by the orography and characterized by high humidity, large variations in temperature, and irregular rainfalls (mean annual rainfall of $800 \mathrm{~mm}$, mean annual temperature of $5-7^{\circ} \mathrm{C},[25]$.

\subsection{Data Constraints}

As rainfall is the primary trigger of torrential events, the main constraint of this study is the lack of long and continuous time series in the basin. There has been a meteorological station in Portainé (at $1985 \mathrm{~m}$ a.s.l.) only since 2011. Thus, for the present work, data from other stations in the region, presented in Figure 1 and Table 1, were used. There are no river gauging stations in the basin. This lack of local data determined the hydrometeorological approach (see Section 5).

Table 1. Basic information on the rain gauges and data used in this study. Data used for long series construction (see Section 5.1.1) correspond to the stations highlighted in bold characters.

\begin{tabular}{ccccc}
\hline \multirow{2}{*}{ Rain Gauge } & \multirow{2}{*}{$\begin{array}{c}\text { Altitude } \\
\text { (m a.s.1.) }\end{array}$} & $\begin{array}{c}\text { Distance to the } \\
\text { Portainé Basin } \mathbf{( k m )}\end{array}$ & \multicolumn{2}{c}{ Measuring Interval (yyyy) } \\
\cline { 4 - 5 } & 1985 & 0 & 2011 & Start \\
\hline Portainé & 1322 & 2.4 & 2010 & - \\
Montenartró & 1300 & 6.3 & 2008 & - \\
Llagunes & 679 & 6.9 & 2009 & - \\
Sort & 850 & 8 & 1915 & 1999 \\
Llavorsí & 2451 & 16.2 & 2004 & - \\
Salòria & 1083 & 18.8 & 1932 & 1959 \\
Capdella & 849 & 19.22 & 1996 & - \\
La Seu d'Urgell & & & &
\end{tabular}

\subsection{The 2006 and 2008 Trigger Events}

Two significant torrential events occurred in 2006 and 2008. In May 2006, the Reguerals ravine obliterated the access road to the ski resort at its highest intersection. At that time, the drainage infrastructure consisted of a pipe of approximately $80 \mathrm{~cm}$ in diameter that was blocked by sediments, causing the passage of the dense flow over the road. This is the first documented road blockage in the area, and most likely reflects system disequilibrium around the geomorphological threshold. The night of 11 to 12 September 2008, the largest torrential event known in the Portainé basin occurred. It coincided with earthworks at the ski resort and resulted from ordinary rains ( $43 \mathrm{~mm}$ at Salòria station, see Section 5.1.3). The talus supporting the road (earth embankment) at the highest crossing of the Portainé stream became saturated and collapsed. This created an erosive breach along the ravine slopes downstream (Figure 2). Highly destructive debris flows moved along both torrents of Portainé and Reguerals, sweeping everything along its path and damaging the Vallespir dam. All intersections of the 
access road were damaged by the clogging of the drainage passages and the consequent deposition on the road. Since then and until 2017, nine destructive torrential avenues occurred in the basin (Table 2).

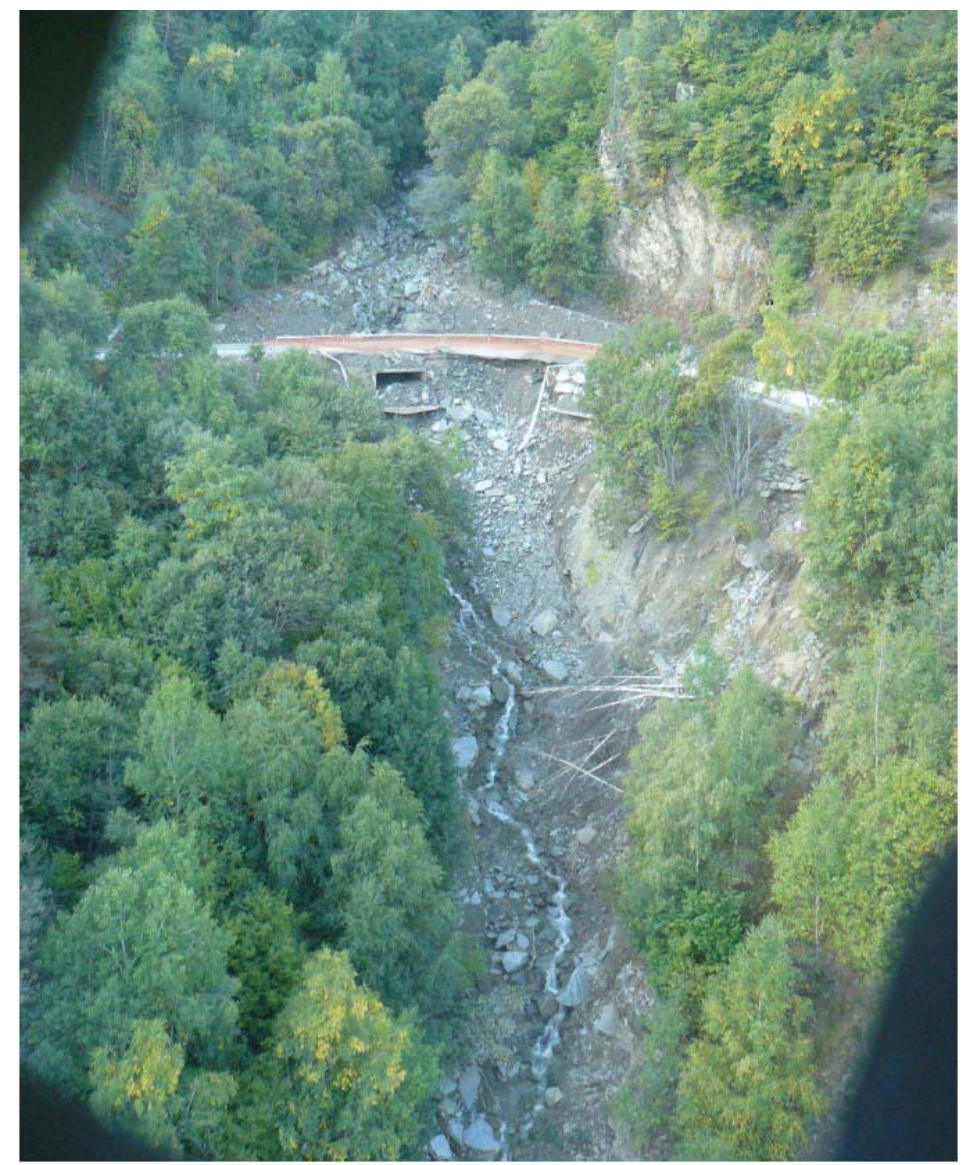

Figure 2. Helicopter view of the erosive breach created by the trigger event of 11-12 November 2008. Image property of ICGC (Institut Cartogràfic i Geològic de Catalunya).

Table 2. Historical record for the occurrence of recent torrential flows in the Portaine catchment and their effects on road intersections, indicated by their altitude (TO: total obstruction of the culvert; PO: partial obstruction of the culvert; C: talus collapse; w: water circulation) and by the downstream debris cone (E: erosion; D: deposition).

\begin{tabular}{|c|c|c|c|c|c|c|c|c|}
\hline \multirow{2}{*}{$\begin{array}{c}\text { Event Date } \\
\text { (day month year) }\end{array}$} & \multicolumn{3}{|c|}{ Portainé } & \multicolumn{2}{|c|}{ Reguerals } & \multirow{2}{*}{$\begin{array}{c}\text { Caners } \\
1035 \\
\text { m a.s.1. }\end{array}$} & \multirow{2}{*}{$\begin{array}{c}\text { No. of Total } \\
\text { Road } \\
\text { Obstructions }\end{array}$} & \multirow{2}{*}{$\begin{array}{l}\text { Debris } \\
\text { Cone }\end{array}$} \\
\hline & $\begin{array}{c}1965 \\
\text { m a.s.l. }\end{array}$ & $\begin{array}{c}1700 \\
\text { m a.s.l. }\end{array}$ & $\begin{array}{c}1450 \\
\text { m a.s.l. }\end{array}$ & $\begin{array}{c}1665 \\
\text { m a.s.l. }\end{array}$ & $\begin{array}{c}1465 \\
\text { m a.s.l. }\end{array}$ & & & \\
\hline May 2006 & & & & & TO & & 1 & \\
\hline $\begin{array}{c}\text { 11-12 September } \\
2008\end{array}$ & $\mathrm{TO}, \mathrm{C}$ & $\mathrm{TO}, \mathrm{C}$ & TO & $\mathrm{TO}, \mathrm{C}$ & TO & $\mathrm{w}$ & 5 & $\mathrm{D}$ \\
\hline 02 November 2008 & & & TO & & & & 1 & \\
\hline 22-23 July 2010 & & & $\mathrm{TO}, \mathrm{C}$ & & TO & & 2 & $\mathrm{E}, \mathrm{D}$ \\
\hline 12 August 2010 & & & $\mathrm{TO}, \mathrm{C}$ & & TO & & 2 & E, D \\
\hline 05 August 2011 & & $\mathrm{PO}$ & TO, C & $\mathrm{w}$ & $\mathrm{w}$ & & 0 & $\mathrm{D}$ \\
\hline 23 July 2013 & & & TO & TO & TO & & 3 & E, D \\
\hline 20 August 2014 & & & & & & & 0 & \\
\hline 30 August 2014 & & PO & TO & & & & 1 & \\
\hline 21 August 2015 & & $\mathrm{PO}$ & TO & & & & 1 & E \\
\hline 29 August 2016 & $\mathrm{PO}$ & & $\mathrm{PO}$ & & & & 0 & \\
\hline
\end{tabular}

There is barely any documented information on destructive torrential events in the Portainé basin prior to 2006; they were mostly unknown until the works presented here (see Section 6). However, since 2009 (notably, since the 2008 events), 6.6 M€ has been invested in road works and 0.5 M€ in mitigation measures, including flexible sediment retention barriers along the streams (Figure 1) [19]. 


\section{Methodology}

To address the problem, a secular time scale, useful for land use management purposes, was considered appropriate. Then, the threshold control factors can be divided into those that remain unchanged at this timescale (lithological and main macro-geomorphological characteristics), and those susceptible to change (land use, vegetation and hydrometeorology), the former representing the intrinsic control factors and the latter the extrinsic ones [20]. The catchment's hydrological response, its alteration due to the anthropogenic land-use change, and the consequent hydrogeomorphic effects must have been a consequence of the evolution, interaction and change in balance among these control factors. Thus, three levels of analysis were performed: the first being the identification and characterisation of the causes of the change, the second the characterisation of particular, local effects and the third the holistic integration of all the acquired knowledge (Table 3).

Table 3. Synthesis of the methodology used to carry out the present research, with 3 levels of analysis and considering causal control factors, local effects and global consequences in the studied basin.

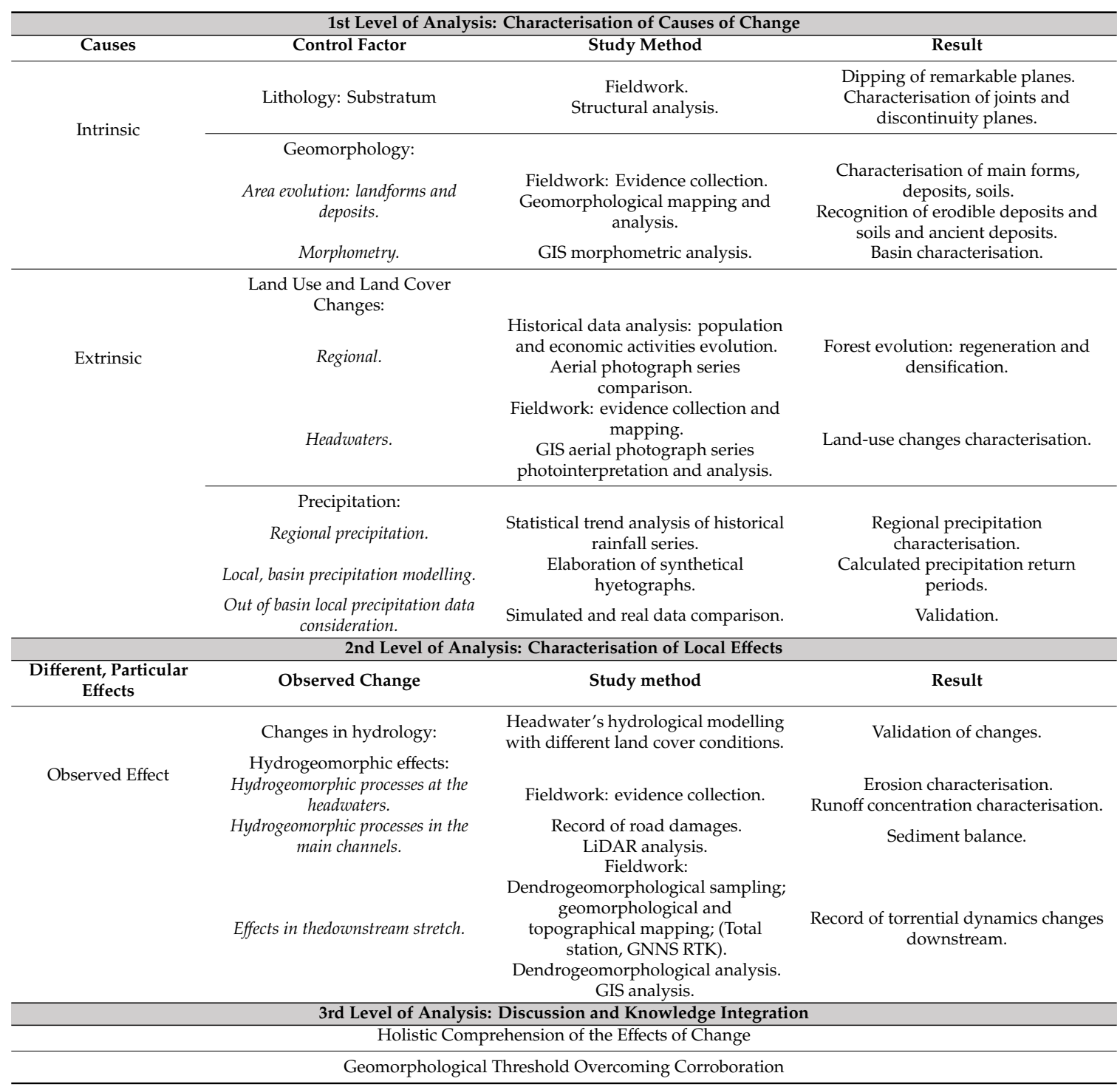




\section{Intrinsic Control Factors: Lithology and Geomorphology}

\subsection{Lithological Characterisation}

Insofar as the terrain properties are a conditioning factor for the soil development and hydrological behaviour of systems, we have carried out a specific geological and structural analysis of the study area.

The Pyrenees is an Alpine intracontinental fold and thrust belt that resulted from the convergence between the Iberian and European tectonic plates from Late Cretaceous to Oligocene times [26]. In the Pyrenees, rocks ranging in age from Late Neoproterozoic to Mississippian form an elongated strip in the backbone of the chain known as the Axial Zone, which is unconformably overlain by Mesozoic and Cenozoic rocks (Figure 1). The rocks that crop out at the Portainé catchment are deformed Cambro-Ordovician metapelites from the Serdinya formation [27], also known as Seo [28] or Jujols [29]. The performed analysis consisted in measuring the structural surfaces of the bedrock at fifteen outcrops, but also in studying any other deposits found within the catchment.

The bedrock consists of slates and phyllites with a principal foliation plane, but also showing several other mesoscale surfaces. On the one hand, we recognize four structural fabrics: S0 bedding (11/019), S1 cleavage (49/203), Sr/S2 regional cleavage (40/026), and S3 subtle cleavage (53/316). These suggest several deformational episodes, with the most remarkable planes (S0 and S2) gently dipping to the north subparallel to the bedding and to the topographic surface (Figure 3; Figure S1 in the supplementary material). On the other hand, we have identified two types of fractures: tectonic jointing (two subvertical sets, parallel and perpendicular to Sr, and usually filled with hydrothermal quartz), in addition to non-tectonic fractures (opened). The latter occur much more intensely near the topographic surface or in vertical road slopes (Figure 3). Moreover, near the topographic surface the bedrock often displays considerable weathering.
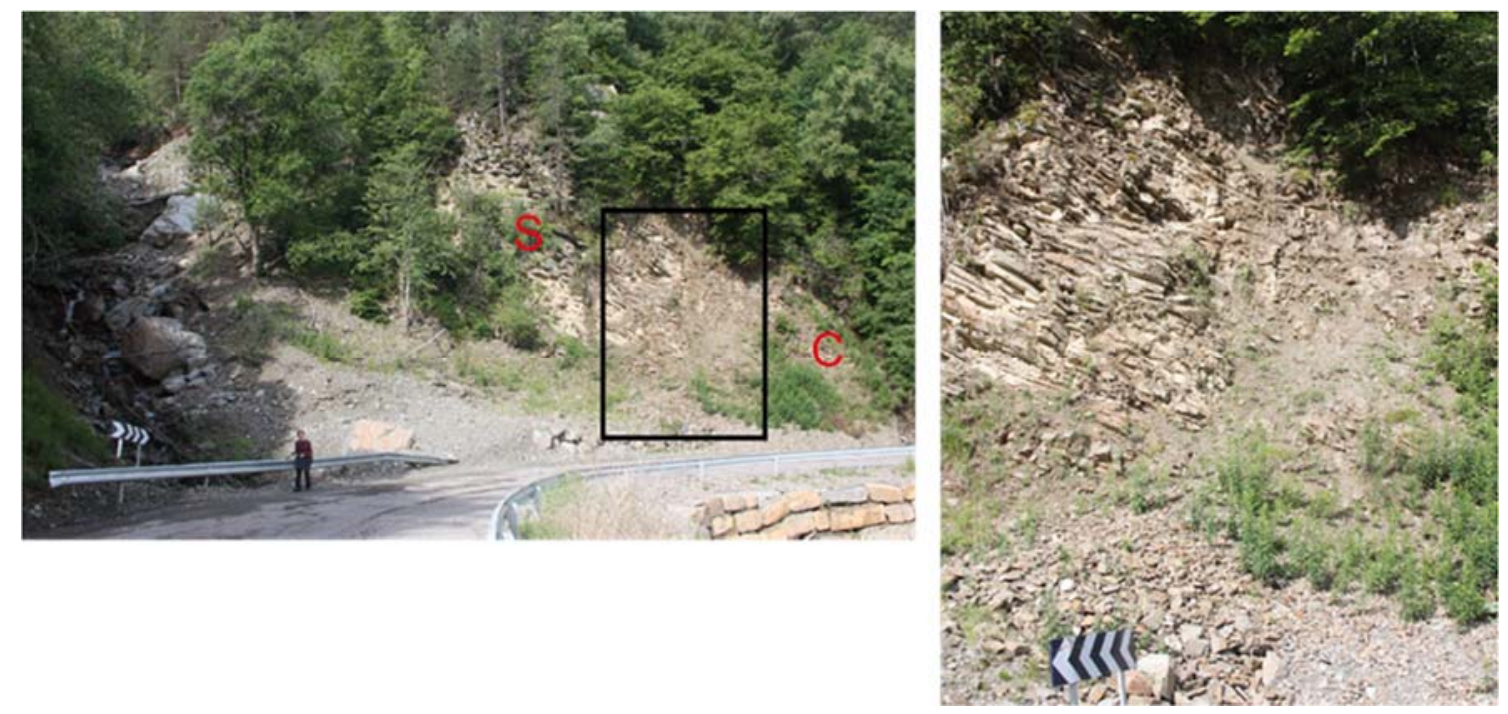

Figure 3. Regional cleavage of the Cambro-Ordovician bedrock subparallel to the topographic surface. Gradual transition from bedrock (S) to colluvium (C). The black square delineates the area in the right picture.

\subsection{Geomorphological Characterisation}

\subsubsection{Evolution of the Area and Present Features}

The main geomorphological features of the area are relict remains of Neogene planation surfaces [30,31] (and references therein), small glacial cirques in the highest areas, and active fluvio-torrential and slope processes affecting the whole territory (Figure 1). The residual planation surfaces correspond to smooth mountain ridges with gentle slopes $\left(<15^{\circ}\right)$, like the one extending 
around the flat top of Torreta de l'Orri [28]. The incision of the main Pyrenean rivers dissecting these surfaces rejuvenated the relief [30]. On a more local scale, the Romadriu river and its tributaries, like those of the Portainé basin, originated high reliefs $(500-1000 \mathrm{~m})$ with narrow valleys and steep slopes (see Section 1.2). Furthermore, during the Late Miocene, the paleoclimate was warm and humid, [32], favouring intense chemical weathering.

Pleistocene glaciations affected the whole Pyrenees [33]. Around Torreta de l'Orri, four cirques -including the one forming the headwaters of Portainé basin — are the southernmost glacial features in the area. Tills and younger rock glacier moraines cannot be clearly observed as they have been eroded, reworked, and incorporated into the slope deposits by postglacial processes, and recently, by construction at the ski resort. The large areas not occupied by glaciers were affected by intense periglacial processes, which produced a large amount of debris that is widely found as thick soils overlaying the bedrock. In the headwaters, there are grèzes litées stratified slope deposits (Figure S2). Downwards, up to $10 \mathrm{~m}$ thick unconsolidated colluvium covers the hillslopes (Figure 2). Lastly, torrential deposits are accumulated along the valley bottoms and in the Portaine basin in the alluvial cone at the end of the stream, coming from the erosion of the bedrock or the colluvium. All of this large quantity of deposits and the superficially highly altered substratum are susceptible to erosion and to be entrained in the torrential floods.

\subsubsection{The Basin's Propensity to Torrential Dynamics}

The susceptibility of the basins to produce floods or dense flows is constrained by their morphometric characteristics. The method developed by [34] distinguishes between basins prone to torrential floods that can convey some bed load, hyperconcentrated flows or debris flows. The method is based on the relation among the following morphometric catchment parameters: (i) area, (ii) length from the cone apex to the most distal point, (iii) basin relief (vertical drop from the highest point to the cone apex), (iv) the Melton ratio (relief/Varea), and (v) relief ratio (relief/length). [35] have already validated this method in Catalonia in more than 50 documented active torrential catchments, including Caners (Figure S3).

The Caners catchment has a length of $5.05 \mathrm{~km}$ and a Melton ratio of $0.62 \mathrm{~km} / \mathrm{km}$, which indicates its morphometric propension to generate hyperconcentrated flows.

Therefore, the basin is prone to generating, in a wide sense, dense flows, both because its morphometry and due to the availability of erodible material. This is also supported by sediment evidence: the depositional cone at the Portainé confluence with the Romadriu river (see next section). However, it is worth noting that in recent decades, before 2006, the basin produced no dense flows that mostly transported some bedload with no damaging consequences.

\subsubsection{Former Evidence of Geomorphological Disequilibrium}

Consistently with the torrential basin proneness, solid evidence of ancient dense flows in the basin exists in the form of characteristic sedimentary deposits, which are presented in the following subsections.

Evidence of large debris flows. Evidence of ancient, large debris flows exists at the lower end of the study area. As will be discussed in Section 7, in this case, ancient means that these dense flows could be generated since the middle of the 20th century and extend back to, at least, the entire Holocene. Some deposits crop out at the right margin of the Romadriu river, in front of the Caners confluence and at an altitude ranging from 5 to $10 \mathrm{~m}$ above the channel (Figure 1). They consist of matrix supported, disorganized and unconsolidated deposits, with heterometric sub-rounded to sub-angular clasts ranging from millimetres to decimetres, protected from erosion inside substratum cavities (Figure S4). Their facies correspond undoubtedly to debris flow deposits. They do not present enough ancient organic detritus and are highly bioturbed by insects and by the roots of the plants growing around, and so they could not be dated by ${ }^{14} \mathrm{C}$ or by OSL techniques. Nonetheless, their high topographic position indicates that they do not correspond to the recent activity of the Portainé basin. 
On the other hand, in the 21 August 2015 torrential event, the sediment entrained in the Portainé stream (Table 2) was mostly retained by the flexible barriers [18]. Thus, unloading of the flow produced erosion downstream in the lower reach of Caners, with the outcropping of ancient sediments (Figure 1) that had been covered by younger torrential deposits. These sediments are shown and described in Figure 4 and correspond undoubtedly to debris flow facies. Up to three flow waves can be distinguished in some outcrops. They were preserved, as in the previously described case, in sheltered topographic irregularities of the margins and the stream channel.
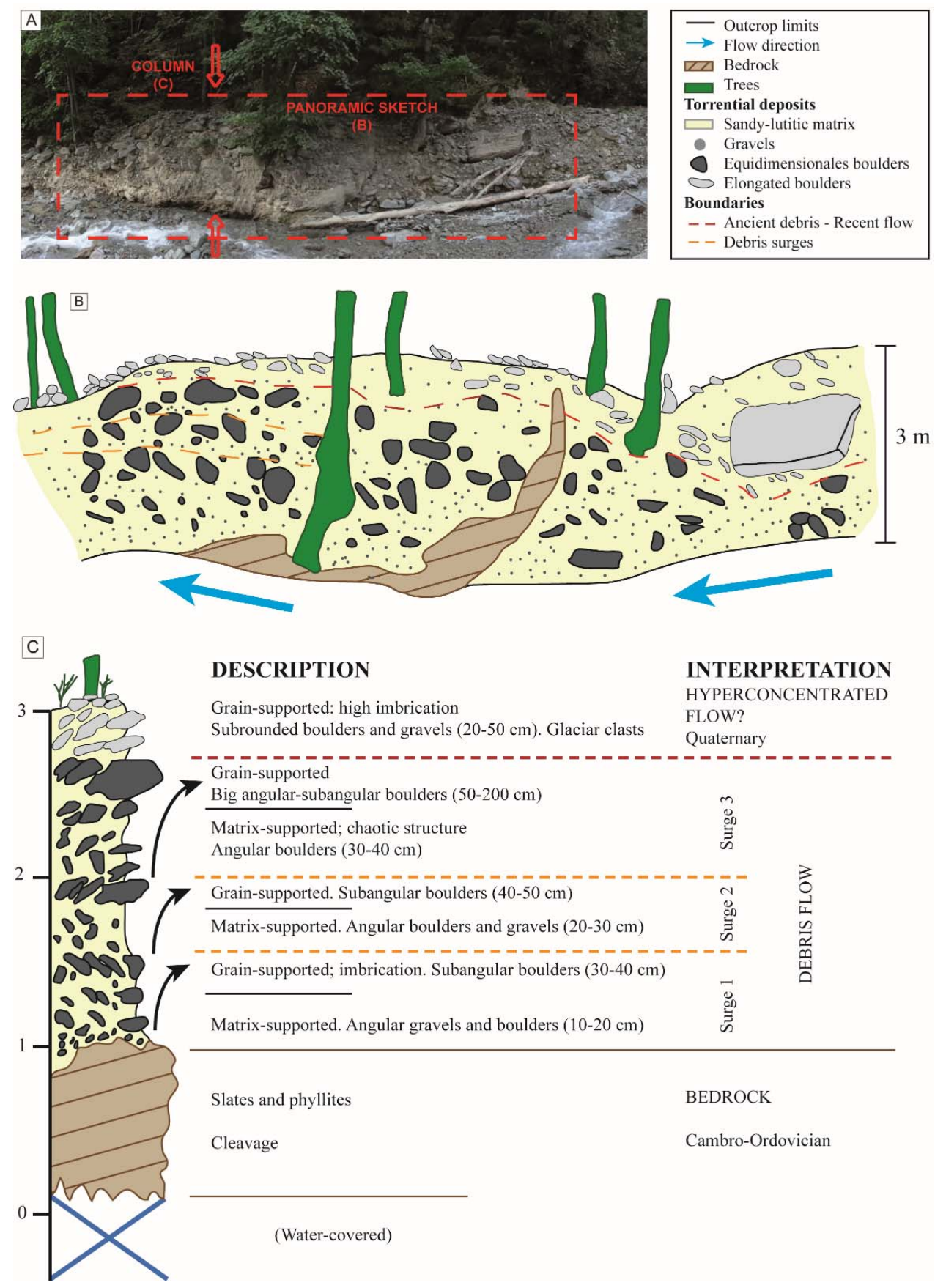

\section{DESCRIPTION}

Grain-supported: high imbrication Subrounded boulders and gravels $(20-50 \mathrm{~cm})$. Glaciar clasts Grain-supported Big angular-subangular boulders $(50-200 \mathrm{~cm})$ Matrix-supported; chaotic structure Angular boulders $(30-40 \mathrm{~cm})$ Grain-supported. Subangular boulders $(40-50 \mathrm{~cm})$

Matrix-supported. Angular boulders and gravels $(20-30 \mathrm{~cm})$ Grain-supported; imbrication. Subangular boulders $(30-40$ ch) Groin-supported; im

Matrix-supported. Angular gravels and boulders (10-20 cm)

Cleavage

Cambro-Ordovician 穴
INTERPRETATION

HYPERCONCENTRATED FLOW? Quaternary

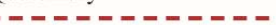

Figure 4. Study of the torrential deposits in the right margin of the lower reach of the Caners stream. (A) Photo of the outcrop and location of the sketch and the column. (B) Panoramic sketch with the interpretation of materials and torrential episodes. (C) Stratigraphic column with the description of the sedimentary packages identified, and the interpretation of the torrential process that generated each of them. 
Evidence of dense overflows. At an altitude of approximately $1300 \mathrm{~m}$ a.s.1., at the "la Borda de Simó" location (Figure 1), there is solid evidence for ancient dense flows. The terrain is shaped in a clearly decametric lobed morphology (Figure S5), product of these dense flows that had overflown their streams and deposited in this gentler sloped area.

It has not been possible to date the age of the lobes to date, but some trees that grow in them have been dated. Ten Pinus sylvestris were sampled; their maximum age is slightly more than 71 years and their average age is a little over 61 years. Even though the precise age of these overflow deposits is unknown, it is prior to the establishment of the trees, i.e., prior to the middle of the 20th century.

\section{Land-Use Changes}

\subsection{General Forest Regeneration: Vegetation Changes in the Lower Part of the Basin}

Depopulation was a significant phenomenon throughout the twentieth century in the Pyrenees and, specifically, in the Pallars Sobirà County. Table 4 illustrates the evolution of the population of the municipality of Rialp since 1920, where Portainé belongs. Note the decrease in population, with a minimum in 1950, and a subsequent increase to the present day. Variations in population were associated with the mortality related to the civil war (1936-1939), with previous and later migration and with changes in economic activities, with the abandonment of agriculture and livestock and the birth and growth of tourism mostly since the nineties [36]. The resulting decrease in the use of the land favoured the forest regeneration. Inferring from the ages estimated in [21] (see Section 6.3), most of the trees were progressively established in the Portaine alluvial cone since the beginning of the 1950s. During previous decades, the left bank of the stream was intensely cultivated and when this stopped, present vegetation colonized the area. Summarising, the forest mainly grew and densified in the area, downward from the ski resort (Figure S6). In this regard, one inhabitant (Mr. J. Montserrat) commented about the Romadriu River: "Not having cattle, there are more trees and the trees drink water when it rains and the floods are smaller". The densification of the vegetation cover suggests that torrential floods in the Portainé basin should be smaller now than in the middle of the 20th century, but what happens is just the opposite.

Table 4. Evolution of the population of the Rialp municipality since 1020 [37].

\begin{tabular}{ccccccccccc}
\hline Year & $\mathbf{1 9 2 0}$ & $\mathbf{1 9 3 0}$ & $\mathbf{1 9 4 0}$ & $\mathbf{1 9 5 0}$ & $\mathbf{1 9 6 0}$ & $\mathbf{1 9 7 0}$ & $\mathbf{1 9 8 1}$ & $\mathbf{1 9 9 1}$ & $\mathbf{2 0 0 1}$ & $\mathbf{2 0 1 1}$ \\
\hline Inhabitants & 704 & 593 & 460 & 382 & 495 & 659 & 415 & 466 & 537 & 664 \\
\hline
\end{tabular}

\subsection{Land-Use Changes in the Headwaters}

The headwater vegetal land cover has been severely disturbed since the ski resort development, as can be clearly seen in Figure 5. We conducted a detailed mapping of the land use (at several year intervals) based on vertical aerial photographs and orthophotos from 1956 to 2014 (Figure S7). Simplified land cover changes are shown in Table 5. Thus, while the forest densified in the region (see previous section), the increase in the area without vegetal cover in Portainé headwaters over time stands out, obviously leading to a decrease in infiltration and water concentration increases (see Section 5.2).

One of the most significant land cover changes is the substitution of the Rhododendron ferrugineum bushes' cover by the ski tracks (Figure 5, Figures S7 and S8). This bushes' cover frequently overlaps a moss and herb cover that grow in quite well-developed organic soil. During rainfall episodes, this vegetal cover intercepts and retains water and the soil facilitates infiltration. Conversely, devegetated ski runs favour surface saturation, runoff and water concentration. Fieldwork conducted in October 2014 allowed us to ascertain that, two days after a rainfall, the mosses under the bushes' cover were still wet while the ski runs were already completely dry. Thus, this land cover substitution favours a decrease in interception and infiltration and aggravates all processes related to water concentration and erosion. 


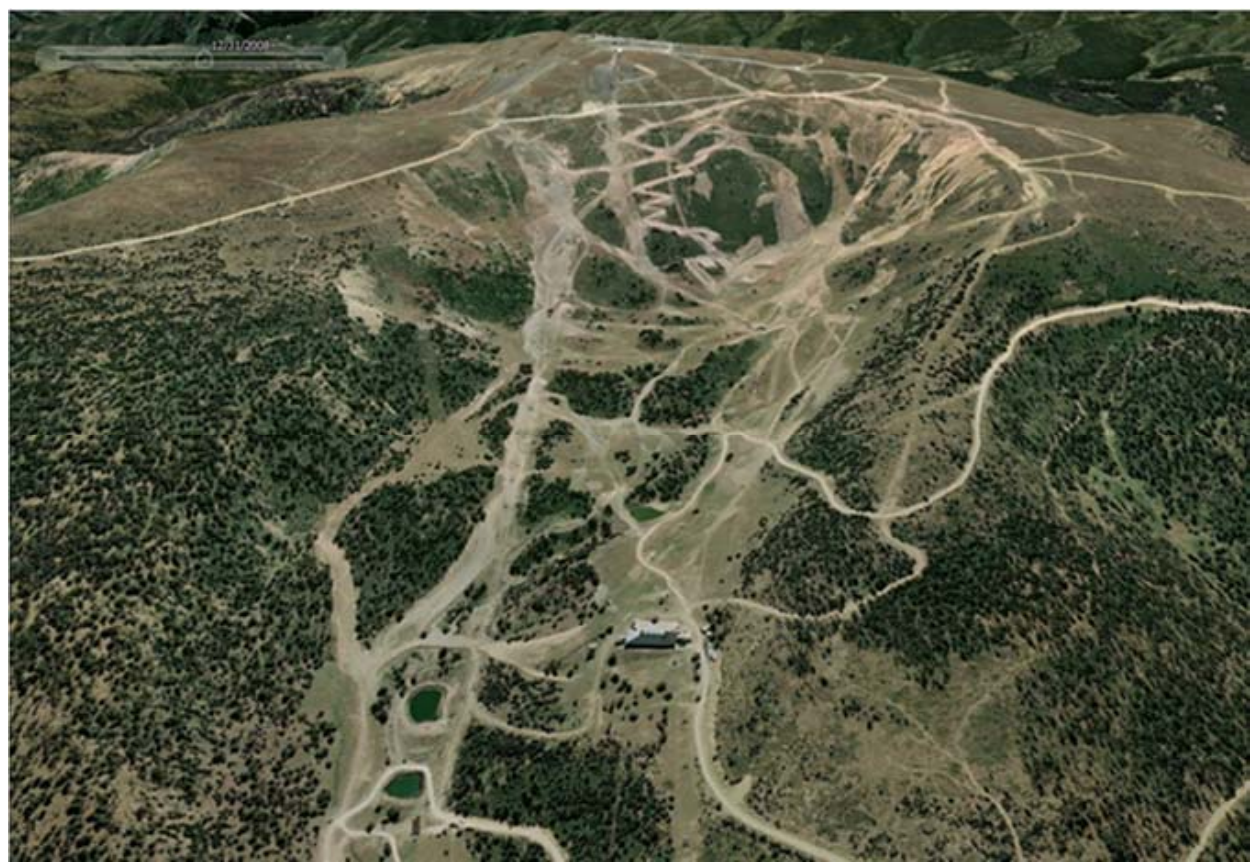

Figure 5. Google earth image (2008) of the headwaters, where the Port Ainé ski resort is located. Impact on vegetation is clearly visible.

Table 5. Areas corresponding to the different types of vegetation and areas without vegetation calculated from the headwater maps (Portainé and Reguerals bsubbasins) and their increments (examples in Figure S7). $\Delta$ expressing increment.

\begin{tabular}{cccccc}
\hline $\begin{array}{c}\text { Type of Vegetation } \\
\text { (Area: } \mathbf{~ k m}^{2} \text { ) }\end{array}$ & $\mathbf{1 9 5 6}$ & $\mathbf{1 9 9 6 - 1 9 9 7}$ & $\mathbf{2 0 0 8}$ & $\mathbf{2 0 1 4}$ & $\mathbf{\Delta ~ 2 0 1 4 - 1 9 5 6}$ \\
\hline Without plant cover & 0.08 & 0.38 & 0.47 & 0.52 & 0.43 \\
Meadows & 0.71 & 0.48 & 0.43 & 0.39 & -0.32 \\
Bushes & 0.36 & 0.15 & 0.12 & 0.12 & -0.24 \\
Open forest & 0.92 & 0.79 & 0.77 & 0.76 & -0.16 \\
Dense forest & 0.66 & 0.93 & 0.93 & 0.92 & 0.26 \\
\hline
\end{tabular}

Besides, water drainage channels were dug obliquely to the ski slopes. This is a technique used to avoid rainwater concentration and erosion along the tracks. The water is collected and diverted to the side of the runs. In Portainé, however, this produces undesired side effects because of the channelized runoff erosion (see Section 5.2). In the ski resort, from 2005 to 2007, $0.24 \mathrm{~km}$ of channels was dug, 6.52 $\mathrm{km}$ more from 2007 to 2011, and $1.58 \mathrm{~km}$ more still from 2011 to 2013, giving a total of $8.34 \mathrm{~km}$ of such channels (Figure S8). These channels also concentrate the surficial water that is redirected to the Portainé and Reguerals streams.

\section{Analysis of Rainfall and Hydrological Response}

\subsection{Analysis of Rainfall Behaviour}

Taking into consideration the lack of rainfall and discharge data in the basin (see Section 1.3), two complementary studies were carried out. The first explores long-term rainfall data series to detect changes in rainfall patterns. The second models synthetic hyetographs. Both are presented in the following sections. Finally, the available data corresponding to the recent torrential events were compared with previous modelling. 


\subsubsection{Trend Analysis of Historic Rainfall Time Series}

The temporal evolution of rainfall during the last hundred years was studied. The goal of this task includes detecting important changes in the precipitation patterns at the beginning of the 21st century, if they occurred. Daily precipitation was assessed, since these types of records represent the only time interval that is available for the historical records.

One of the major concerns in the analysis of rainfall trends is the creation of a long time series. As stated above, the Portainé rain gauge was installed in 2011 and only a discontinuous time series is available. Thus, data from other stations are needed to construct the time series (Figure 1; Table 1).

Fortunately, the Llavorsí rain gauge, which is located approximately $7 \mathrm{~km}$ north of the Portainé basin, includes data from 1917 to 1999. However, there is a large gap between 1932 and 1959 because of the Spanish Civil War. The main criterion to fill this gap and to extend the time series until the present was to take into account the data of the closest available rain gauge. Finally, data from four different rain gauges were used (Sort, Llavorsí, La Seu d'Urgell, and Capdella).

As a first step, the daily rainfall values of two gauges are compared for the time span of available data at both of them (Figure S9). The results show that the correlation between Llavorsí and Capdella is especially poor, while the other correlations are acceptable from a meteorological point of view. The disagreement between Llavorsí and Capdella, which is reflected by the much higher daily precipitation at Capdella, is caused because this rain gauge is located in another river valley (Figure 1) and at a higher altitude (Table 1). These circumstances produce higher annual precipitation at Capdella (approximately $1250 \mathrm{~mm}$ ) than at Llavorsí $(720 \mathrm{~mm})$. Thus, a correction to the Capdella records is necessary to fill the gap of the Llavorsí time series.

Finally, a linear regression model between the two rain gauges is applied to estimate the daily rainfall of the final time series. The gap between 1999 and the present was directly filled by the rainfall records measured at La Seu d'Urgell and Sort.

The daily precipitation records between 1917 and 2017 for the Portainé region were used to analyse the general patterns and to detect some important changes in rainfall conditions (Figure S9). This complete time series includes two days with rainfall depths larger than $100 \mathrm{~mm} / \mathrm{d}$ and seven days with values larger $80 \mathrm{~mm} / \mathrm{d}$.

From a general point of view, no change in extreme events is visible. For a detailed analysis, the occurrence of heavy rainfall events was evaluated at annual and decadal periods. The number of daily rainfall events that accumulated more than three critical values, Pcr, were calculated (Pcr equal to 30,40 , and $50 \mathrm{~mm} / \mathrm{d}$ ). The results do not show any significant increase in heavy rainfalls during the last hundred years. Performing a linear regression analysis, the three data series only reveal small augmentations (Figure $6 \mathrm{~b}$ ) and very low $\mathrm{R}^{2}$-values. For $\mathrm{Pcr}=50 \mathrm{~mm} / \mathrm{d}$ the slope of the trend line is almost zero, while the one for $\mathrm{Pcr}=30 \mathrm{~mm} / \mathrm{d}$ is 0.01 . Although this analysis is simple and preliminary, the results show that the higher torrential activity observed in the Portainé basin seems to be related to other factors than a recent increase in rainfall activity (discussed in previous/subsequent sections of this paper). However, a more sophisticate statistical analysis of the rainfall time series may be implemented in a future study applying tests like Mann-Kendall (see [38]). 
(a)

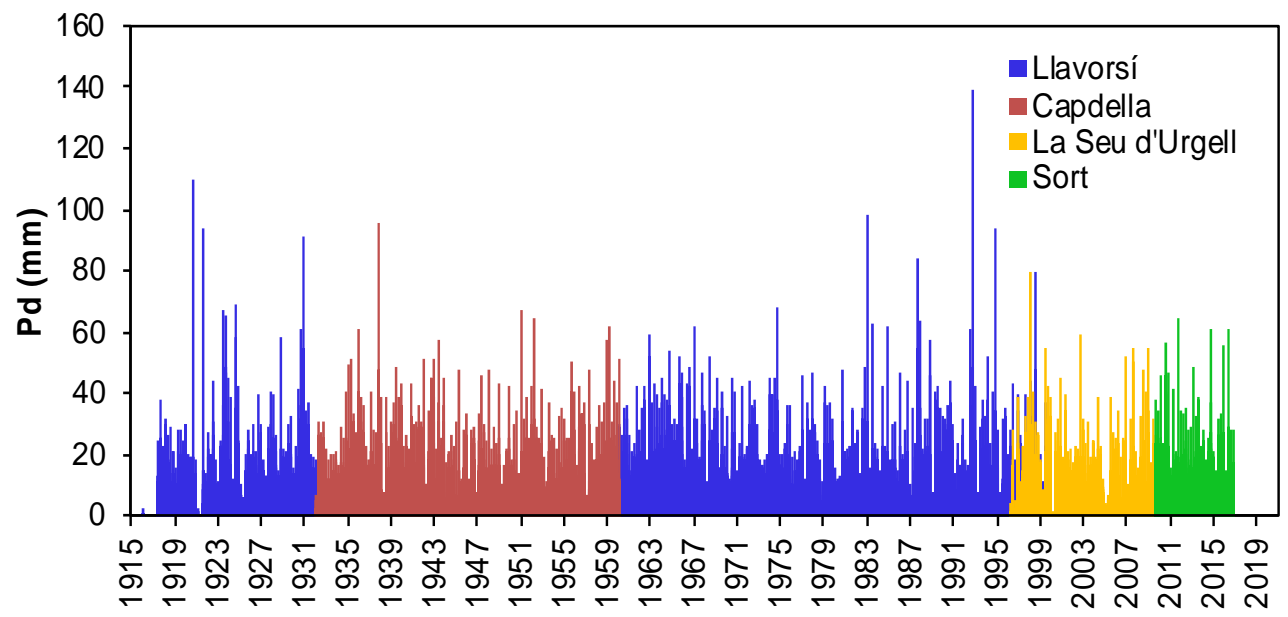

(b)

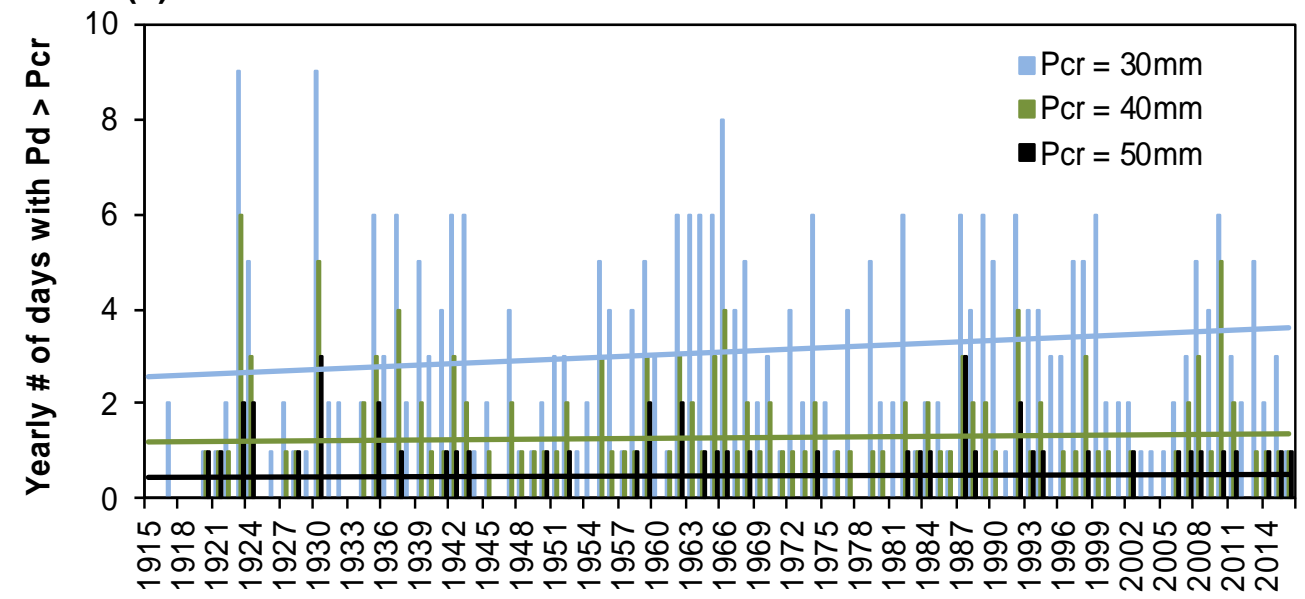

(c)

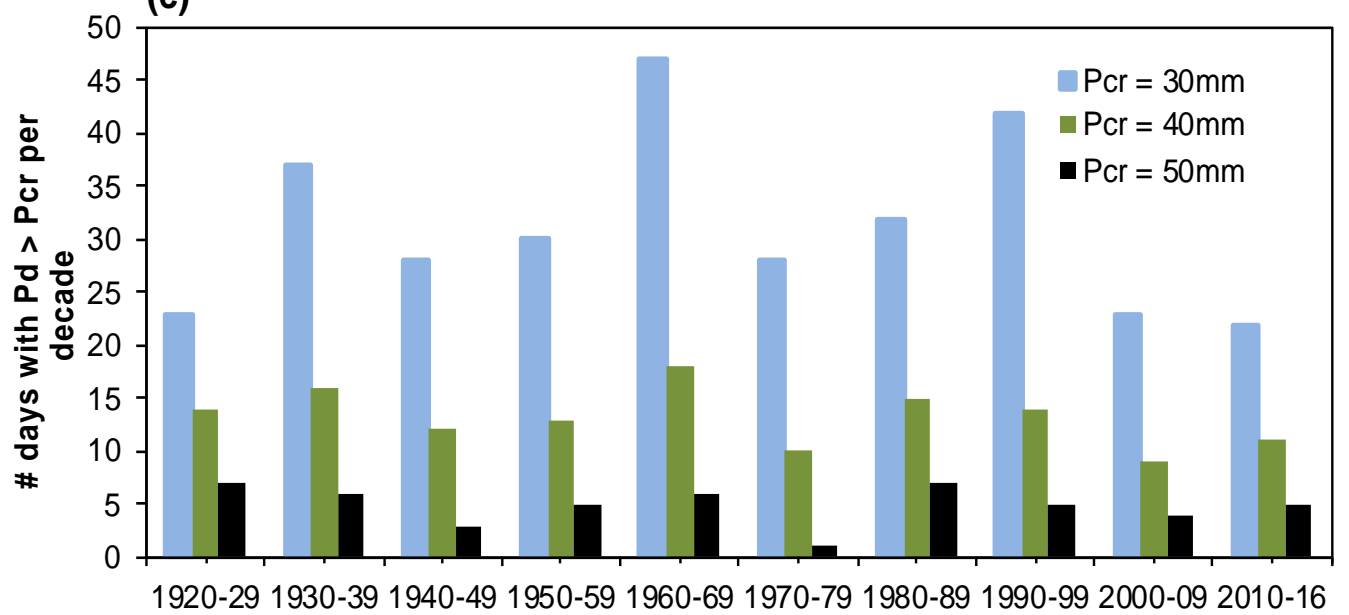

Figure 6. Analysis of rainfall trends for the Portainé area. (a) Complete time series of daily rainfall $\left(\mathrm{P}_{\mathrm{d}}\right)$. (b) Number of heavy rainfall events exceeding critical daily rainfall $\left(\mathrm{P}_{\mathrm{cr}}\right)$ per year. Linear regression models are included with the same colour as the bars. (c) Number of heavy rainfall events exceeding $\mathrm{P}_{\text {cr }}$ per decade. 


\subsubsection{Elaboration of Synthetic Hyetographs}

To compare the hydrological response of the basin before and after the settlement of the ski resort (see Section 5.2), synthetic hyetographs were calculated [16]. As the objective was to compare two different time scenarios, a rainfall regionalisation procedure, complementary to the previous analysis (see Section 5.1.1), was considered useful enough. Based on the official publication "Maximum daily precipitation in the Peninsular Spain" [39], we used MAXIN software [40] to consistently obtain the rainfall return periods' regionalisation. The SQRT-ETmáx extreme-distribution function was used and the maximum daily rains associated with the 10, 50, 100, and 500 year return periods (T) were obtained: $85,118,133$, and $172 \mathrm{~mm} /$ day, respectively.

Next, the rainfall intensities were calculated from the annual maximum daily rainfall for a time interval equivalent to the concentration time (tc) based on the formulation of [41]. For each one, a centred hyetograph was created to represent the variation of the intensity of the precipitation over $24 \mathrm{~h}$ (Figure 7). Other asymmetric patterns of hyetographs (event beginning biased and event end biased) were also tested but discarded.

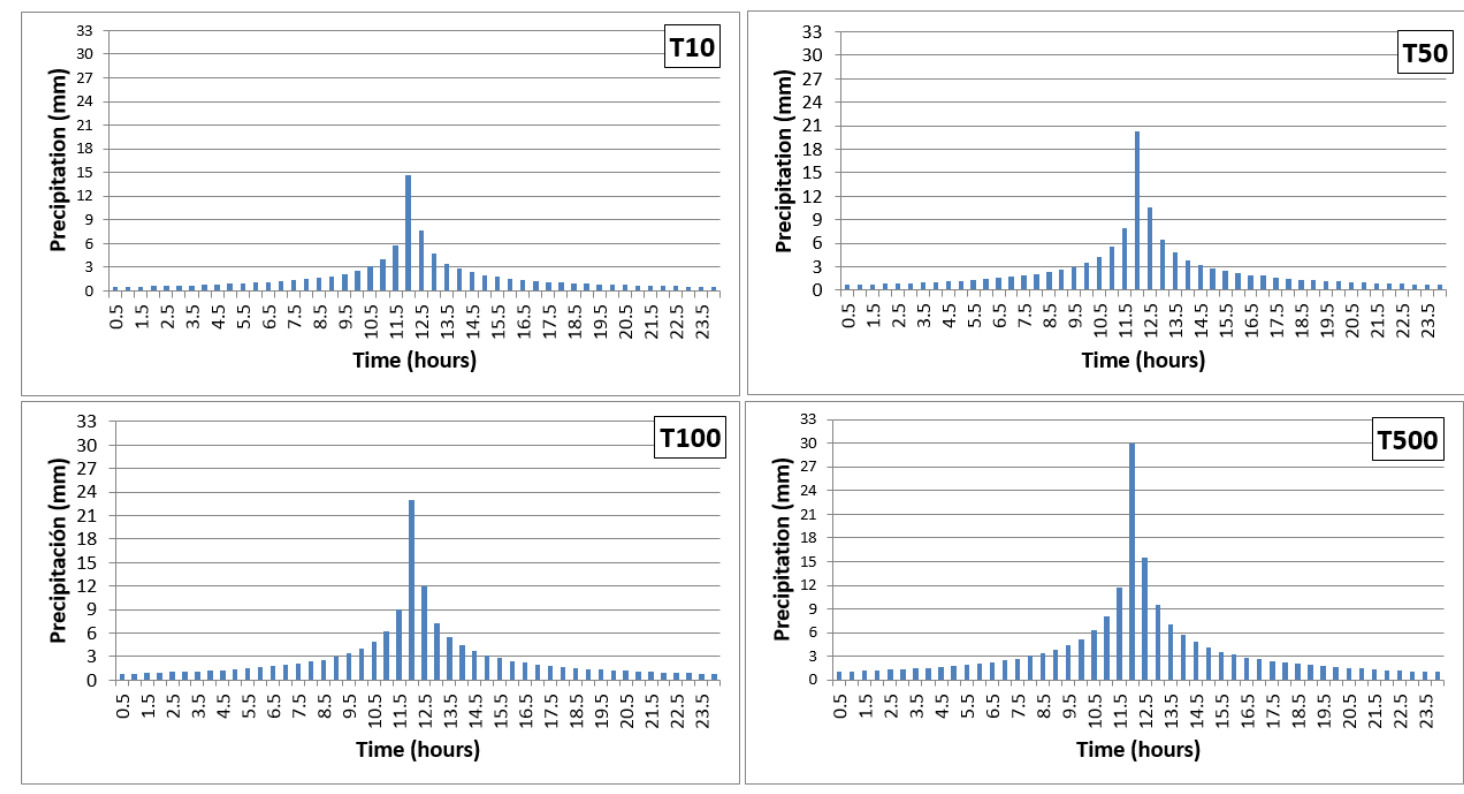

Figure 7. Synthetic hyetographs for return periods of 10, 50, 100, and 500 years.

These synthetic hyetographs obtained were used to evaluate the changes in hydrological behaviour in the headwaters of the basin, as input of rainfall-runoff models, as explained in Section 5.2.

\subsubsection{Other systematic and non-systematic knowledge on precipitation}

In the Pallars Sobirà county, maximum intensity and frequency rainfall events occur in spring and summer, mainly as convective storms [25]. Orography controls the generation of convective cells at the top of the drainage basins [42] which enhances precipitation, as in the Portainé summit. The torrential events in Portainé, thus, are mostly related to intense and localized convective summer rainstorms (witnesses' pers. comm.) and [25].

From 2011 to 2017, six rainfall events that produced floods were recorded at several meteorological stations at hourly intervals, including Portainé. Values vary widely, mostly due to the rainfalls' convective nature. The comparison of daily synthetic hyetographs values (T10) with the real, recorded rainfall values (Figure 8A) show that the recorded ones are smaller than the synthetic ones, which is logical because the real precipitation occurs almost annually. But when comparing the hourly rainfall intensities (Figure 8B), the real values are higher than the T10 synthetic ones, highlighting that very intense rainfalls occur almost yearly. 


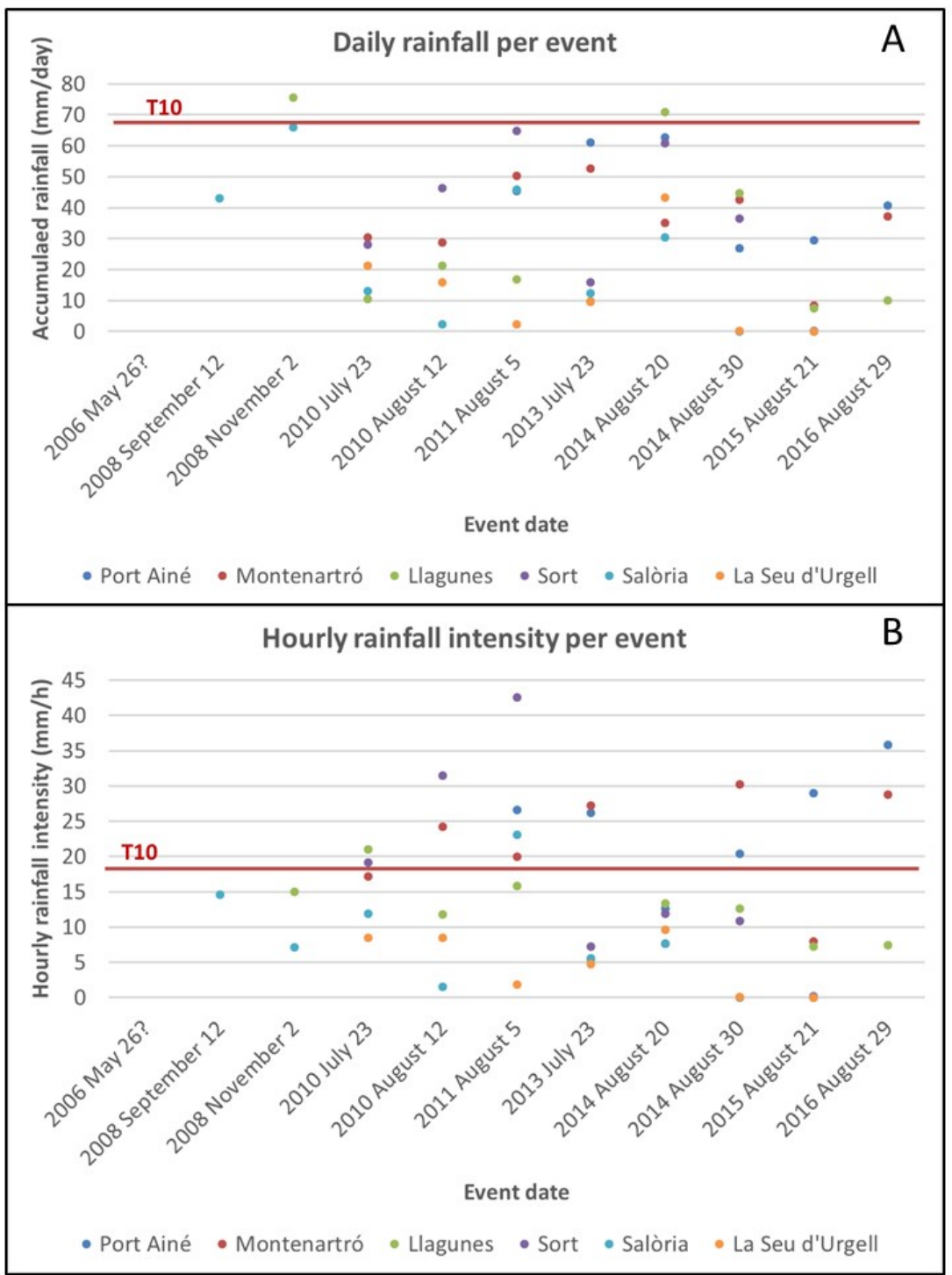

Figure 8. Comparison among the daily (A) and maximum hourly (B) rainfall intensity per event for the different meteorological stations close to and including Portainé. The calculated T10 daily rainfall value and the T10 hourly rainfall value extracted from the hyetographs, presented in Section 5.1.2, are shown with a red line.

\subsection{Changes in the Hydrological Behaviour of the Basin's Headwaters}

The hydrological response of the basin before and after the settlement of the ski resort was compared. The methodology used is presented broadly in [16]. To perform this comparison, hydrological methods of rainfall-runoff transformation were chosen. Two basin models were generated with GIS tools and basin model schemes were created with the HEC-HMS 4.0 software for the scenario prior to the ski resort settlement and for the current one. Three runoff models were created by using the "Curve Number" (CN) method of the U.S. Soil Conservation Service [43,44], implemented in the HEC-HMS software. The generated synthetic hyetographs (see Section 5.1.2) were used as input meteorological model. Integrating all these and by using the HEC-HMS 4.0 software, three hydrological rainfall-runoff models were built: (i) 1956, prior to the ski resort development; (ii) 1996, after completion of the ski resort; and (iii) the current scenario. To simulate the net rainfall transformation into runoff, the SCS Unit Hydrograph method was chosen; a non-existent base flow was considered since there are no permanent rivers and the torrential ravines are very dependent on the rains. For the flow wave propagation, the Muskingum method [45] was applied (the parameters $x$ and $k$, needed for the method, 
were calculated with the NWS FLDWAV model and are shown in Table S1). Several control points, shown in Figure 9 and considered in Table 5, were used for the hydrological simulations.
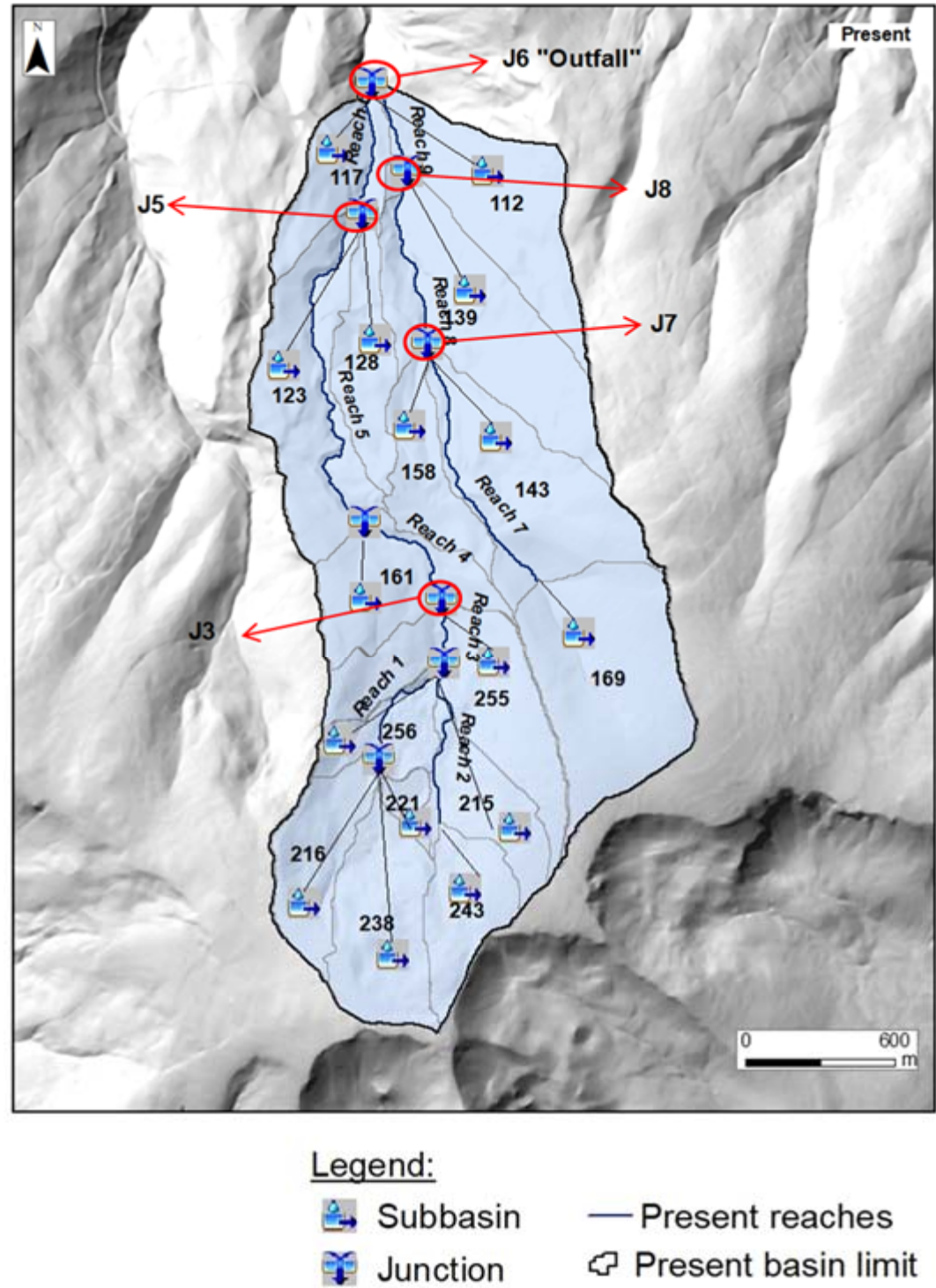

Figure 9. Portainé and Reguerals modelled basins and sub-basins using HEC-HMS software. The junctions or "control points" J3, J5, J6, J7, and J8 corresponding to Table 5 are highlighted.

The results (Table 6) show that there are significant differences in peak flows at the confluence of the Portainé and Reguerals torrents (J6). In general, the greater ones are detected in T10, mainly due to the soil cover influence (and therefore the $\mathrm{CN}$ ) in response to the smaller rainfalls. Therefore, the differences decrease with increasing return periods. The land-cover alterations produced between 1956 and present are larger in Portainé than in the Reguerals headwaters. Therefore, the control point $\mathrm{J} 3$ is the one showing the major increase in discharge, reaching up to $26 \%$ for T10 and coinciding with the largest increase in the ski slopes' surface in recent years (Figure S10). Meanwhile, at point J8 in Regerals, a reduction of $11 \%$ is observed, which is likely due to an increase or densification in the forest cover. In general terms, the models show an increase in discharge of $15 \%$ for T10 at point J6. This increase in discharge can only be interpreted by taking into account the land-cover transformation. 
Table 6. Hydrological modelling results. The different return periods considered and the consequent peak flow discharges $\left(\mathrm{m}^{3} / \mathrm{s}\right)$ at the control points $\mathrm{J} 3, \mathrm{~J} 5, \mathrm{~J} 6, \mathrm{~J} 7$ and $\mathrm{J} 8$ are shown. \% indicates the percentage of change between the 1956 and present situations.

\begin{tabular}{|c|c|c|c|c|c|c|c|c|c|c|c|}
\hline \multirow{3}{*}{$\operatorname{Tr}$} & \multirow{3}{*}{ Situation } & \multicolumn{10}{|c|}{ Control Points (Junctions) } \\
\hline & & \multicolumn{2}{|c|}{ J6 } & \multicolumn{2}{|c|}{ J5 } & \multicolumn{2}{|c|}{$\mathrm{J} 3$} & \multicolumn{2}{|c|}{$\mathrm{J} 8$} & \multicolumn{2}{|c|}{$\mathrm{J} 7$} \\
\hline & & $\begin{array}{l}\text { Peak } \\
\text { Flow }\end{array}$ & $\%$ & $\begin{array}{l}\text { Peak } \\
\text { Flow }\end{array}$ & $\%$ & $\begin{array}{l}\text { Peak } \\
\text { Flow }\end{array}$ & $\%$ & $\begin{array}{l}\text { Peak } \\
\text { Flow }\end{array}$ & $\%$ & $\begin{array}{l}\text { Peak } \\
\text { Flow }\end{array}$ & $\%$ \\
\hline \multirow{3}{*}{10} & Present & 8.1 & \multirow{3}{*}{15} & 5.6 & \multirow{3}{*}{23} & 4.6 & \multirow{3}{*}{26} & 2.2 & \multirow{3}{*}{-9} & 1.9 & \multirow{3}{*}{-11} \\
\hline & 1996 & 7.8 & & 5.4 & & 4.44 & & 2.1 & & 1.8 & \\
\hline & 1956 & 6.9 & & 4.3 & & 3.4 & & 2.4 & & 2.1 & \\
\hline \multirow{3}{*}{100} & Present & 20.5 & \multirow{3}{*}{7} & 12.9 & \multirow{3}{*}{14} & 10 & \multirow{3}{*}{15} & 6.7 & \multirow{3}{*}{0} & 5.2 & \multirow{3}{*}{7} \\
\hline & 1996 & 20.3 & & 12.8 & & 9.9 & & 6.3 & & 5.1 & \\
\hline & 1956 & 19.1 & & 11.1 & & 8.5 & & 6.7 & & 5.6 & \\
\hline \multirow{3}{*}{500} & Present & 32.4 & \multirow{3}{*}{4} & 19.5 & \multirow{3}{*}{9} & 14.7 & \multirow{3}{*}{10} & 11.2 & \multirow{3}{*}{2} & 8.5 & \multirow{3}{*}{4} \\
\hline & 1996 & 32.3 & & 19.5 & & 14.8 & & 10.5 & & 8.4 & \\
\hline & 1956 & 31 & & 17.7 & & 13.2 & & 11 & & 8.9 & \\
\hline
\end{tabular}

\section{The Present Hydrogeomorphic Effects}

\subsection{The Processes in the Headwaters}

Elimination of vegetation and anthropic modifications lead to changes in the headwaters' processes, increasing erosion and leading to water discharge concentration downwards.

The initial effects of rainfall water concentration over the ski slopes are rill erosion and flow sediment load increase derived from the eroded, stratified soils (see Section 3.2.1), thus generating heavily loaded flows. These entrained sediments deposit as accumulations and lobes of angular, coarse gravels when the flow energy decreases, so when the slope angle is reduced, or the flow decelerates because of obstacles. However, when the flow unloads, the cleaner, concentrated water continues moving downwards (Figure S11) and contributes to increasing discharges in the Portainé and Reguerals streams.

The drainage water channels dug on the ski runs (Section 4.2) concentrate rainfall waters efficiently. The undesired side effects are the deepening of the channels and soil degradation, new incisions, channel head new development and enhanced rill and gully erosion (deeper than $1 \mathrm{~m}$ ) at the margins of the ski runs (Figure 10), also observed by Fidelus-Orzechowska et al. [46] and Ristić et al. [47] in the Southern Poland and East Serbia ski resorts and deeply studied and characterized by Wrónska-Wałach et al. [48] in a ski resort in Poland. In the case of Portainé, this also leads to higher water concentrations and an increase in the discharges at the lower end of the facility, coherently with the hydrological modelling (see Section 4.2).

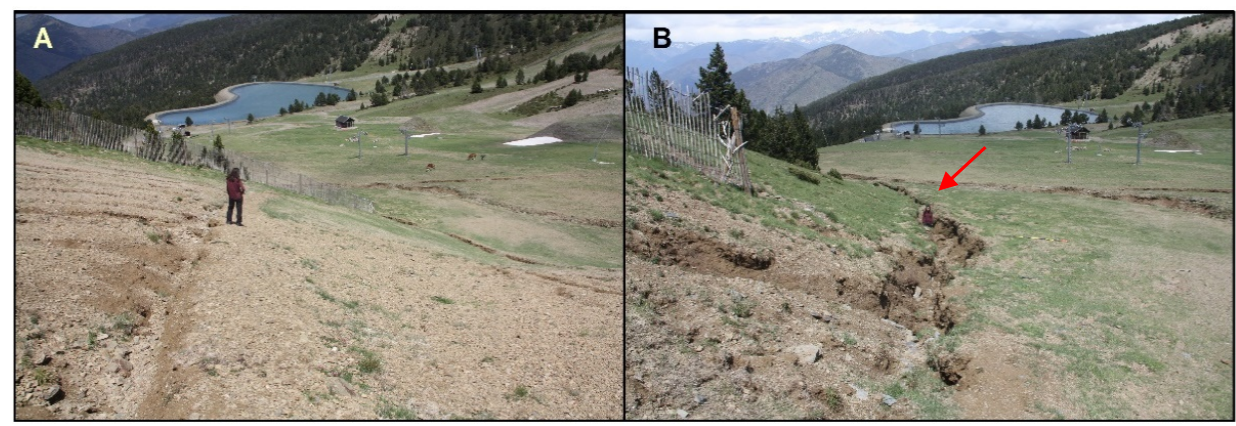

Figure 10. Pictures of the erosion on the basin headwaters due to land-use changes and enhanced by drainage water channels and concentration of runoff. (A) drainage water artificial channel and (B) gully erosion downstream; for a better appreciation of the scale, note the person in the channel highlighted with a red arrow. 


\subsection{Hydrogeomorphological Processes along the Main Channels}

Hydrogeomorphological activity reaches its maximum intensity along the intermediate and lower reaches of the torrents, posing a severe risk to road infrastructures (e.g., road intersections). These processes have been assessed during post-event field surveys [12,13,15], but they are restricted to specific debris flow or flood events. The geomorphic change detection and quantification in this area has been systematically performed by the comparison of sequential bare-earth Digital Terrain Models (DTMs) obtained from airborne LiDAR data from 2009, 2011, and 2016 [22].

LiDAR-based DTM differencing shows a complex erosion-deposition pattern of the channels throughout time during the studied period. Erosion was the predominant dynamics along valley bottoms. The material that is eroded from the torrent bed and banks is susceptible to being transported by the flow, thus increasing its sediment load, especially during high discharge events. Other localized incisions have been identified, such as downstream and lateral scouring at sediment retention barriers, and enhanced entrenchment downstream of the road intersections. Depositional processes rather prevailed locally and mostly correspond to human-altered stretches. Indeed, these phenomena occurred due to the filling of the barriers, to the obstruction of underground drainage channels at road intersections, or to sediment being deposited in the alluvial cone during extraordinary torrential events.

During the 2009-2011 period, 22,042 $\mathrm{m}^{3}$ and 19,204 $\mathrm{m}^{3}$ of material were eroded and accumulated, respectively (-2838 $\mathrm{m}^{3}$ sediment budget), whereas, in 2011-2016, even if the time period was considerably longer, the activity was less intense, and the erosion and deposition volumes were only $8308 \mathrm{~m}^{3}$ and $8161 \mathrm{~m}^{3}$ (-147 $\mathrm{m}^{3}$ sediment budget). Budget segregation analyses showed the spatio-temporal distribution of those geomorphic changes (Figure 11). The Portainé torrent is the most erosive one. Caners tends to be aggradational, and Reguerals varies over time. It is noteworthy that erosion prevails in the upper sector of the catchment (headwaters). When dividing the drainage network into shorter reaches, a complex hydrogeomorphic dynamic arises as a result of the interference between the natural channel evolution and the influence of barriers. Moreover, 2008 post-event field data revealed that the most intense erosion occurred along two specific stretches of the Portainé torrent (1930-1645 $\mathrm{m}$ a.s.l. and 1555-1387 $\mathrm{m}$ a.s.l.), which became predominantly depositional after barriers were installed in 2010. These differences prove the undeniable geomorphic impact of the structural measures, that significantly alter flow hydrodynamics.

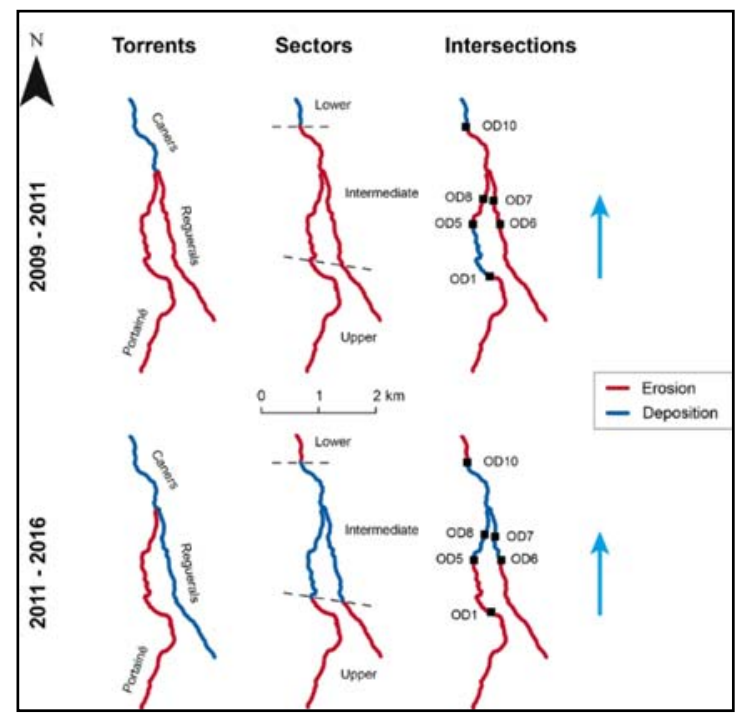

Figure 11. Sediment budget segregation by dividing the channels according to different criteria: drainage network (torrents), mean channel gradient (catchment sectors) and road intersections. Blue arrows indicate flow direction. 


\subsection{Record of Changes in the Torrential Dynamic in the Downstream Stretch}

A dendrogeomorphological study was carried out in the cone, at the downstream stretch of Caners [21]. One hundred and sixty-six samples from 67 trees belonging to 10 different species were analysed, which are representative of the broadleaf forest in the downstream stretch (Figure 12). The main identified macroscopic indicators of flood damage were wounds, decapitations (loss of the main stem), tilting, stem burial and dead trees. Sampling mainly consisted of extracting cores using a standard Pressler increment borer; additionally, we also obtained some wedges from heavily damaged or dead trees. We dated 364 Flood Dendrogeomorphological Evidence (FDE), mainly scars and decapitations, growth changes and tree ages.
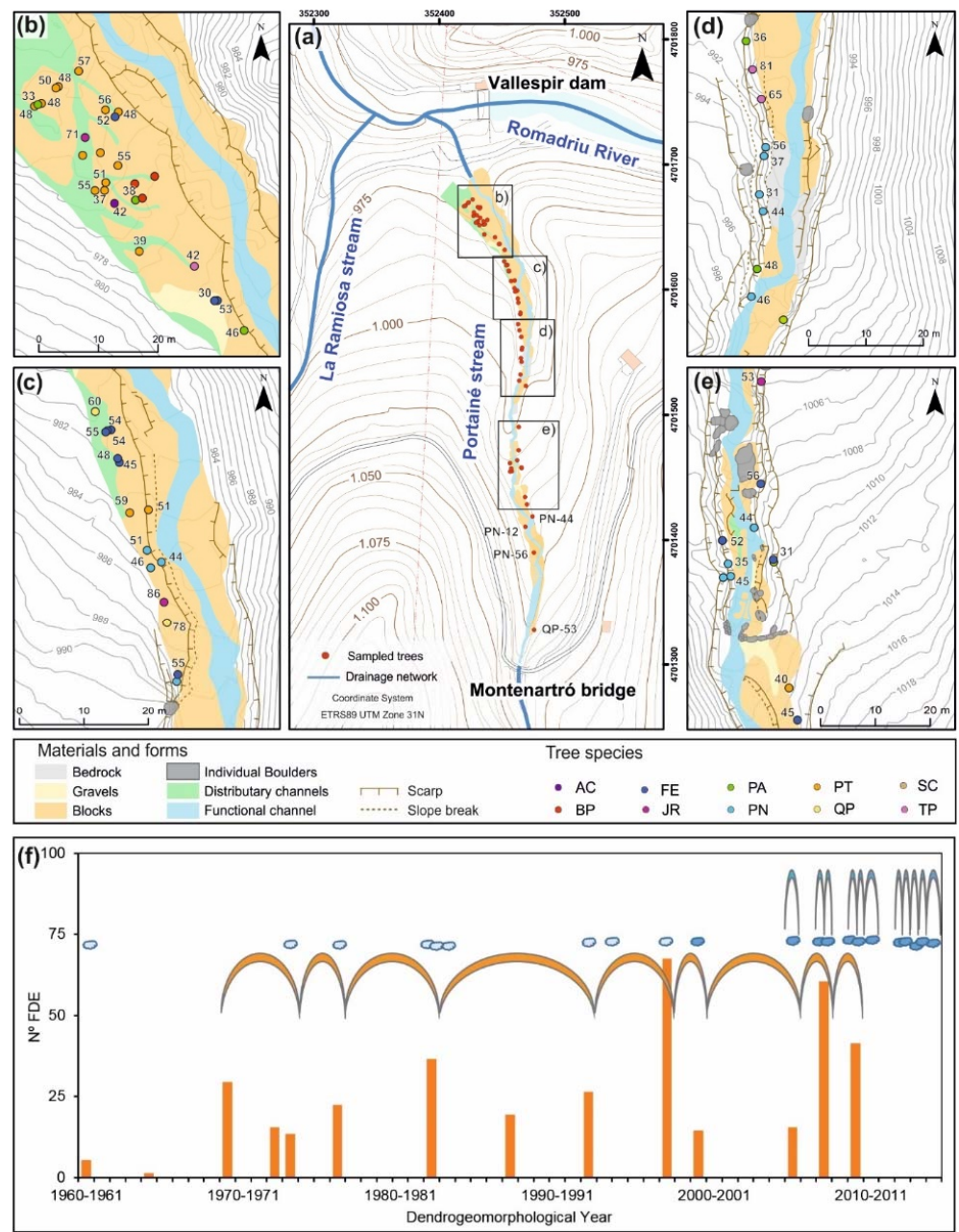

Figure 12. (a) Geomorphic forms at the Portainé cone and location of the 67 sampled trees. Black boxes show the stream stretches enlarged in (b-e) that show the main geomorphic forms and materials as well as the sampled trees, with the species indicated by colours and the estimated age by numbers. In the southern part of the study area, the scattered trees are identified with the species code and the estimated age. Species code: AC—Acer campestre L., BP-Betula s.p. L., FE-Fraxinus excelsior L., JR-Juglans regia L., PA-Prunus avium L., PN—Populus nigra L., PT-Populus tremula L., QP-Quercus petraea (Matt.) Liebl., SC-Salix caprea L., TP-Tilia platyphyllos Mill. (f). Number of dated FDE (columns in orange) and documented events of regional (light blue clouds) or local (dark blue clouds) rainfalls. The arcs represent the well-defined event-to-event intervals determined by the Flood Dendrogeomorphological Evidence (arcs in orange colour) and by the documented local events rainfalls since 2006 in the Portainé stream (arcs in grey colour). 
We also determined ten well-defined Dendrogeomorphological Years (DYs), when the events that affected the trees were identified by the temporal overlaps of many FDEs. The patterns of FDE distribution are subject to uncertainties because of the limitations of the method, for example, the different tree-ages. However, the maximum and average ages of many tree species were similar, indicating their first establishment in the 1950s. In addition, these data were compared with the available documentary record. This multi-evidence data about temporal distribution of torrential floods and event-to-event intervals from the last 60 years demonstrate the recent change in frequency of destructive torrential flows (Figure 12f).

These dendrogeomorphological event-to-event intervals determined between 1969-1970 and 2009-1910 are shown in Figure 12f. The average recurrence interval is 4.5 years and the median, 4 years. In contrast, the documented data available on local rainfalls and debris events from 2006 to 2016 show that the average recurrence interval was almost 1 year (Figure 12f). No interval of such a high frequency occurred before, during the second half of the 20th century. Even though it is not possible to derive the type of torrential flow and its density from the FDE, the obtained results show an undeniable increase in destructive flows over the last decade. These results are in agreement with the hypothesis of surpassing a geomorphological threshold.

\section{Discussion}

The Portainé basin shows a very complex set of factors that characterize it and drive its dynamic behaviour. As pointed out by [49], interrelationships and scale effects may be difficult to capture in model cascade approaches. Our work presents an alternative to this model cascade approach. Next, all the factors presented above are related and compared in order to acquire a holistic understanding and to corroborate the surpassing of a geomorphological threshold in the basin.

Firstly, the lithological and geomorphological characteristics (Sections 3.1 and 3.2) define a basin prone to sediment-laden torrential flows. The folded and fractured bedrock-with major structures gently dipping subparallel to the topography, and with open fractures near the surface and major weathering - on the one hand favour its erodibility and, on the other hand the formation of deep soils and colluvial deposits. The relief evolution, together with chemical and physical weathering, produces these deposits, and so the material available to be entrained by the flows is effectively unlimited [50]. In addition, the basin morphometry also indicates its tendency to generate dense flows (see Section 3.2.2; [34]. The sediment-laden flows' activity is not continuous and uniform over time but is intermittent and episodic. There must be coinciding critical values of the hydrometeorological parameters (intensity or duration of rain, soil moisture, runoff concentration...) for them to take place. Solid evidence for the occurrence of ancient, non-dated debris flows, and the existence of, at least, a period with not very dense flows in the basin, between the middle of the 20th century and 2006 (see Sections 1.4 and 3.2.3), suggests the shifting of the torrential dynamics from highly active periods, producing very dense, sediment-laden flows, to other less active periods, with more or less bed load transport depending on the flood magnitude. Thus, the adaptive cycle [51] of this system shows that it may exist in at least two steady states, flipping from one to another as its geomorphological threshold is transgressed, as acknowledged by [7] for multiple steady state systems. In that sense, the extrinsic threshold of [50], corresponding to a certain precipitation value that triggers dense flows, can change over time depending on the state of the basin, being a lower value when steady state conditions are similar to the current ones and, thus, favour sediment-laden torrential flows.

As a first approximation, it should have been presumed that the flood magnitudes had been similar to those nowadays during the last hundred years, since rainfall does not show significant pattern changes, as seen in Section 5.1.1. It is worth noting that the values of the rainfall return periods obtained from the historical rainfall time series (Section 5.1.1) are very consistent with those obtained from synthetic hyetographs (Section 5.1.2), which makes our analyses robust. In addition, our results coincide well with those obtained by [52], who describe a period of low frequency and intensity of precipitation from 1917 to 2012, recorded in the varved sediments of Montcortés Lake (approximately 
$20 \mathrm{~km}$ southwest of Portainé). In their study, these varved sediments included clastic layers deposited because of heavy rainfalls; the dating provided by the varved layers corresponds very well to the 80-90 mm rainfall events recorded at the Capdella meteorological station, which corresponds to 2-5 years return period rainfalls. However, in Portainé, changes in discharges happen, as revealed by the hydrological modelling (Section 5.2), and they are due to land cover changes. Discharge changes due to ski resort land cover changes are evaluated quantitatively in the present work, being this pioneer in such evaluation in ski resorts. Among these changes, the anthropic land cover alteration due to the ski resort settlement is obvious: while the forest densified because of the cattle decrease during the last half of the 20th century (Section 4.1), the area without vegetal cover in the headwaters grew (Section 4.2). This caused a significant increase in discharges downstream, additionally enhanced by the drainage channels of the ski slopes (Section 4.2). This is consistent with the observations of [48], where drainage channels redirect water from the ski runs and link with the adjacent valley system, producing a new hydrological state and reactivating erosion processes downstream. When the geomorphological threshold of the basin is overcome, discharges are more effective in eroding, entraining sediment, and transporting it in the form of sediment-laden flows. The effects are similar to those observed by [47] throughout the Zubska riverbed, with the demolishing of bridges, filling of road culverts with sediment, and the destruction of the road system. It should also be recalled that the high intensity of convective, characteristic summer storms (Section 5.1.3) occur almost yearly (corresponding to a calculated return period of $>\mathrm{T} 10$ ). This indicates that the discharge increases expected for T10 (Section 5.2) can, in fact happen yearly, enhancing and aggravating the occurrence of debris and hyperconcentrated flows. As it is in hydrology, the processes and their effects are non-linear $[49,53]$, and so it may be that this increase is even higher. Moreover, the multi-evidence dendrogeomorphological analysis, which also detected the change in flood frequency since 2006 and especially since 2008, but not before (Section 6.3), also supports the disturbance of the geomorphological equilibrium, occurred when the human induced flow concentration coincided with both the earthworks at the ski resort and intense but no extraordinary rainfalls. This type of paleohydrological evidence is especially useful in mountain basins, being a complement to, an alternative, or even the only source of data when there is no systematic and instrumental information available [54].

The erosion becomes particularly effective since the triggering events of 2006 and, especially, of 2008, which swept away the torrential margins' vegetation cover, which had stabilized the ravines until that moment, and created the erosive breach that left the fractured and weathered bedrock and colluvium deposits unprotected and therefore susceptible to erosion (Section 1.4). Thus, vegetation seems to play a key role in the stability of the basin and its dynamics in several ways and over several scales in this small basin, including its influence on the parameters that control discharges (interception, soil moisture, infiltration ... ) and the stability of the torrent margins. As it was pointed out by [49,55], abrupt changes in watershed response can occur as a result of land-use change and can be particularly severe at small scale basins. Our study also corroborates this statement.

Lastly, it should be noted that the recent human intervention in the torrents, with the installation of sediment retention barriers, causes complex dynamics, where the sediment balance is altered (less sediment is exported from the basin), some very erosive stretches have turned into sedimentary ones, and vice versa. Indeed, the barriers attenuate some of the geomorphic effects. Nevertheless, it must be pointed out that sediment-laden torrential flows still occur and could continue occurring if the steady state of the basin remains. To help reverse these dynamics, the land use of the headwaters should be re-considered, and the vegetation cover re-established. This could favour a shift to other steady state characteristics of the basin, less prone to generating dense flows.

Regarding ancient dense flows, they could have been related to periods of decreased vegetal cover, especially in the headwaters. The Holocene variation of the treeline ecotone, or the zone of contact between subalpine forest and alpine meadows without arboreal vegetation, was studied through interdisciplinary palynological and charcoal study methods by Cunill et al. [56] at the upper Cardós river valley, just to the north of the Romadriu valley. Their results show well-established forests up 
to $2200 \mathrm{~m}$ a.s.l. since the beginning of the Holocene, reaching $2460 \mathrm{~m}$ a.s.l. from 9600 to $7600 \mathrm{cal} \mathrm{BP}$. The first openings in the forest occur at approximately $7500 \mathrm{cal}$ BP. From 5100 to $2200 \mathrm{cal}$ BP, there is clear archaeological evidence of human occupation in the high mountains and there were related recurrent burns in order to maintain pastures. In the 6th century (1400 cal BP), there was a generalized intensification in human activity, with more creation and preservation of pastures and altitude cereal crops. The period of maximum deforestation occurred between the 15th and 16th centuries (500-400 cal BP), and at the end of the 19th century the forest recovered favouring a higher treeline. However, their data from charcoals show that there has been an almost uninterrupted history of fires from 10,800 cal BP until the mid-20th century, which could have been from natural on anthropic origin. Taking this into consideration, the ancient debris flows in the Portainé basin could have occurred at any time during the Holocene, related to natural or anthropic forest fires deforestation of the headwaters. Human activity since the Middle Ages and consequent clearing make the generation of these dense flows more likely. Unfortunately, it has not yet been possible to date these deposits, as commented in Section 3.2.3.

On the other hand, it is well known that mass movements are widely linked to climate change, for instance, to the melting and retreat of the glaciers (decompression of the glacial deposits and water addition) [57]. This could have been the case for the Portainé ancient, large debris flows. Furthermore, Abrantes et al. [58] recognised an early period (900-1100 years CE) characterized by intense precipitation/flooding and warm winters. Llasat et al. [59] distinguish an increase in flood events in Catalonia for the periods 1580-1620, 1760-1800, and 1830-1870 A.D. that coincide with different Western Mediterranean area basins and demonstrate a singular but common answer to climatic anomalies. These wet periods could also have favoured the generation of the Portainé ancient, undated dense flows, especially because of their coincidence with deforestation. In conclusion, while it has not been possible to precisely date the ancient Portainé debris flows deposits, their generation could have been related to anthropic or natural forest fires and deforestation, to particularly wet periods, or to a combination of both factors.

Finally, it must be considered that climate change, alteration of atmospheric composition, land-use changes, wildfires and biological invasions threaten forests in the entire Mediterranean basin. Each one of these factors or a combination of them have led to land degradation, vegetation regeneration decline, and expansion of forest diseases [60] recently. One example is the pine processionary caterpillar that is currently spreading throughout the Pyrenees [61]; it can accelerate tree mortality and favour fires and deforestation. In the Pyrenees, according to [62], the frequency and intensity of heat waves is projected to increase, and so the risk of forest fires is expected to increase as well. Furthermore, precipitation is predicted to globally decrease but the number of intense rainfall episodes will increase [63]. All these projections point to future degradation of the forest cover, the soil and, consequently, this would enhance the generation of dense sediment-laden flows in Portaine and other similar basins in the area.

The establishment of quantitative thresholds for variables that condition the triggering of slope movements is a necessary scientific exercise, and even an essential technique [64]. But when the systems are more complex (such as in this case study), combining sudden floods and dense washout flows, the establishment of thresholds must be approached from a multidisciplinary and multivariate perspective, not only in magnitude, but in time.

\section{Conclusions}

The Portainé basin shows a very complex set of factors, described, characterised and analysed by means of the multidisciplinary research presented here, that determines its flood dynamic behaviour. The holistic understanding of this complex watershed can only be appreciated by taking into account the interactions of the lithosphere, atmosphere, hydrosphere, biosphere, and anthroposphere. This means considering the bedrock geology, the geomorphological evolution, the derived soils and colluvial deposits, the rainfall characteristics, and the hydrological response. Its alteration due to the anthropic land-use change, the consequent hydrogeomorphic effects, flood characteristics and the 
role of vegetation must not be misunderstood. The consideration of all the interactions leads us to conclude that a geomorphological threshold has been overcome recently (2006-2008), producing a shift in the torrential dynamics of the basin that turned into very dense, highly erosive sediment-laden flows. Moreover, the basin has shifted around this threshold, giving rise to the two distinct behaviours or equilibrium conditions likely throughout all its Holocene history, as demonstrated by periods of moderate, bed load-laden flow dynamics and by the existence of deposits of ancient debris flows.

Present conditions and projected climate change suggest that the current dynamics are likely to continue despite the efforts to stabilise the most active torrent stretches. In order to avoid worse effects in the future, interventions in the headwaters with close surveillance should be carried out, particularly focussing on revegetation. Moreover, in future research, other nearby, similar basins should be studied in order to check whether they could suffer the same type of threshold surpass and therefore change in flood dynamics.

Supplementary Materials: The following are available online at http:/www.mdpi.com/2073-4441/12/2/368/s1 (ZIP-Document). Figure S1: Regional cleavage of the Cambro-Ordovician bedrock subparallel to the topographic surface. Figure S2: Gréze Litée type deposit located in the headwaters of the Portainé basin. Figure S3: Diagram showing the Melton ratio versus the watershed length and the different types of torrential flows proposed by Wildford et al. (2004). Figure S4: A picture of one of the large, ancient and undated debris flow deposits located at the right margin of the Romadriu River, downstream from the Vallespir dam and in front of the confluence of the Caners stream. Figure S5: Lobed terrain morphology at the area of La Borda de Simó corresponding to overflow deposits of dense flows. Figure S6: Evolution of the vegetation downstream from the ski resort since 1945-1946, showing an increase in trees and dense forest until the present. Figure S7: Land cover maps of the Portainé basin headwaters for 1956, 1996, and present. Figure S8: Drainage channels built since 2005 and up to 2007, 2011, and 2013 in order to divert runoff and avoid erosion on the ski slopes. Figure S9: Availability of rainfall records for the four rain gauges and comparison of daily rainfall, Pd, measured at different rain gauges. Figure S10: General view of the Rhododendron ferrugineum cover located near the ski slopes and of a devegetated ski run. Figure S11: Results of the runoff concentration and sediment deposits at the ski resort. Table S1: Muskingum parameters values ( $x$ and $\mathrm{k}$ ) used for each reach $(\mathrm{Cn})$ of each stream (Reguerals and Portainé), and for the network situations on 1996/56 and at present. The parameters were calculated by using the NWS FLDWAV model. A constant value of $x=0.35$ was assigned because the high longitudinal river slope, with null attenuation; the equation $K=0.7 * t c$ was used for $\mathrm{k}$ values estimation for each propagation reach (where $t c$ is the time of concentration).

Author Contributions: Conceptualisation, G.F., A.V., and A.D.-H.; Methodology G.F., A.V., A.D.-H., M.G. (Mar Génova), M.G. (Marta Guinau), Á.D.1.H., R.M.P., M.H., G.K., J.M.C., A.M., J.P., and M.G. (Marta González); Investigation, G.F., A.V., A.D-H, M.G. (Mar Génova), M.G. (Marta Guinau), Á.D.l.H., R.M.P., M.H., G.K., J.M.C., A.M., J.P., and M.G. (Marta González); Formal Analysis, G.F., A.V., A.D.-H., M.G. (Mar Génova), Á.D.1.H., R.M.P., M.H., J.M.C., and A.M.; Writing-Original Draft Preparation, G.F., A.V., M.G. (Marta Guinau), Á.D.1.H., R.M.P., M.H., and J.M.C.; Writing-Review and Editing, G.F., A.V., A.D.-H., M.G. (Mar Génova), M.G. (Marta Guinau), and M.H. All authors have read and agreed to the published version of the manuscript.

Funding: This work was supported by the following Projects: CHARMA (MINECO, Ref.: CGL2013-40828-R), PROMONTEC (MINEICO-FEDER, Ref.: 444 CGL2017-84720-R), SMuCPhy (MINEICO, Ref.: BIA 2015-67500-R), and two Projects of MINECO (CGL2015-66335-C2-1-R and CGL2017-87631-P); by an APIF scholarship (UB) and by a FI 2018 scholarship (Secretaria d'Universitats i Recerca; Departament d'Empresa i Coneixement; Generalitat de Catalunya); and by the IGME's Program of Professional Practices.

Acknowledgments: We want to thank J. Calvet, R Juliá and M.A. Marqués (UB); C. Fañanás (Dpt. d'Agricultura, Ramaderia, Pesca i Alimentació, Generalitat de Catalunya); the FGC and ICGC personnel, the Arxiu Comarcal del Pallars Sobirà personnel; Ll. Pla (MeteoPirineu) and the hydroelectric company OPYCE (S.A).

Conflicts of Interest: The authors declare no conflict of interest. The funders had no role in the design of the study; in the collection, analyses, or interpretation of data; in the writing of the manuscript, or in the decision to publish the results.

\section{References}

1. Goudie, A. IAG Glossary Of Geomorphology (version 1.0). International Association of Geomorphologists, 2014. Available online: http://www.geomorph.org/wp-content/uploads/2015/06/GLOSSARY_OF_ GEOMORPHOLOGY1.pdf (accessed on 14 February 2018).

2. Schumm, S.A. Geomorphic thresholds and complex response of drainage systems. In Fluvial Geomorphology; Morisawa, M., Ed.; State University of New York: Binghamton, NY, USA, 1973; Volume 13, pp. 299-310. 
3. Schumm, S.A. Geomorphic Thresholds: The Concept and Its Applications. Trans. Inst. Br. Geogr. 1979, 4, 485-515. [CrossRef]

4. Brunsden, D.; Thornes, J.B. Landscape Sensitivity and Change. Trans. Inst. Br. Geogr. 1979, 4, 463-484. [CrossRef]

5. Coates, D.R.; Vitek, J.D. Thresholds in Geomorphology; Allen \& Unwin Pty: Sydney, Australia, 1980.

6. Nanson, G.C.; Huang, Q. A philosophy of rivers: Equilibrium states, channel evolution, teleomatic change and least action principle. Geomorphology 2018, 302, 3-19. [CrossRef]

7. Gregory, K.J. The Earth's Land Surface: Landforms and Processes in Geomorphology; Sage Publications: London, UK, 2010.

8. Wohl, E.E. Rivers in the Landscape.; Wiley Blackwell: Chichester, West Sussex, UK, 2014.

9. Dust, D.W.; Wohl, E.E. Quantitative technique for assessing the geomorphic thresholds for floodplain instability and braiding in the semi-arid environment. Nat. Hazards 2010, 55, 145-160. [CrossRef]

10. Watson, C.C.; Biedenharn, D.S.; Thorne, C.R. Stream Rehabilitation; Cottonwood Research LLC: Fort Collins, CO, USA, 2005.

11. Wilshire, H.G. Human causes of accelerated wind erosion in California's deserts. In Thresholds in Geomorphology. Binghamton Symposium; George Allen \& Unwin: London, UK, 1980; Volume 9, pp. 415-433.

12. ICGC. Estudi de la torrentada de la nit del dia 11 al 12 de setembre de 2008 al barranc de Portainé (Pallars Sobirà); AP-046/10; Generalitat de Catalunya: Barcelona, Spain, 2010.

13. ICGC. Nota de la visita al barranc de Portainé (Pallars Sobirà) arran del episodi de pluges dels dies 22 i 23 de juliol de 2010, AP-046/10; Generalitat de Catalunya: Barcelona, Spain, 2010.

14. Victoriano, A.; Díez-Herrero, A.; Génova, M.; Guinau, M.; Furdada, G.; Khazaradze, G.; Calvet, J. Four-topic correlation between flood dendrogeomorphological evidence and hydraulic parameters (the Portainé stream, Iberian Peninsula). Catena 2018, 162, 216-229. [CrossRef]

15. Abancó, C.; Hürlimann, M. Estimate of the debris-flow entrainment using field and topographical data. Nat. Hazards 2014, 71, 363-383. [CrossRef]

16. De las Heras, Á. Modificación de la respuesta hidrológica en avenidas torrenciales ante los cambios de usos del suelo en una cuenca de montaña (Portainé, Pirineo leridano); Universidad Politécnica de Madrid: Madrid, Spain, 2016.

17. Ortuño, M.; Guinau, M.; Calvet, J.; Furdada, G.; Bordonau, J.; Ruiz, A.; Camafort, M. Potential of airborne LiDAR data analysis to detect subtle landforms of slope failure: Portainé, Central Pyrenees. Geomorphology 2017, 295, 364-382. [CrossRef]

18. Palau, R.M.; Hürlimann, M.; Pinyol, J.; Moya, J.; Victoriano, A.; Génova, M.; Puig-Polo, C. Recent debris flows in the Portainé catchment (Eastern Pyrenees, Spain): Analysis of monitoring and field data focussing on the 2015 event. Landslides 2017, 14, 1161-1170. [CrossRef]

19. Pinyol, J.; Hürlimann, M.; Furdada, G.; Moysset, M.; Palau, R.M.; Victoriano, A.; González, M.; Moya, J.; Raïmat, C.; Fañanás, C. El barranco de Portainé (Pirineo Central): Un laboratorio in situ completo para el estudio de la actividad torrencial. In IX Simposio Nacional sobre Taludes y Laderas Inestables; Centre Internacional de Màtodes Numèrics en Enginyeria (CIMNE): Barcelona, Spain, 2017; Volume 2013, pp. 1165-1176.

20. Furdada, G.; Guinau, M.; Subiela, G.B.; Moraru, A. Las cuencas de Portainé y Romadriu: Susceptibilidad al cambio y factores de control antrópicos y naturales. In Geomorfología del Antropoceno. Efectos del cambio Global sobre los procesos geomorfológicos; García, G., Gómez-Pujol, L., Morán-Tejada, E., y Batalla, R., Eds.; Sociedad Española de Geomorfología: Palma, Spain, 2018; pp. 335-338.

21. Génova, M.; Díez-Herrero, A.; Furdada, G.; Guinau, M.; Victoriano, A. Dendrogeomorphological Evidence of Flood Frequency Changes and Human Activities (Portainé Basin, Spanish Pyrenees). Tree-Ring Res. 2018, 74, 144-161. [CrossRef]

22. Victoriano, A.; Brasington, J.; Guinau, M.; Furdada, G.; Cabré, M.; Moysset, M. Geomorphic impact and assessment of flexible barriers using multi-temporal LiDAR data: The Portainé mountain catchment (Pyrenees). Eng. Geol. 2018, 237, 168-180. [CrossRef]

23. Kondolf, G.M.; Piégay, H. Tools in fluvial Geomorphology.; Ohn Wiley \& Sons Ltd.: Chichester, UK, 2003.

24. Carreras, J. Flora i vegetació de Sant Joan de l'Erm i de la Vall de Santa Magdalena (Pirineus catalans); Col.lecció estudis; Institut d' Estudis Ilerdencs: Lleida, Spain, 1993; Volume 3, pp. 1-321.

25. Meteocat. Atles Climátic de Catalunya 1961-1990; Servei Meteorològic de Catalunya: Barcelona, Spain, 2008.

26. Muñoz, J.A. Evolution of a continental collision belt: ECORS-Pyrenees crustal balanced cross-section. In Thrust Tectonics; McClay, K.R., Ed.; Springer: Dordrecht, The Netherlands, 1992; pp. 235-246. 
27. Padel, M. Influence cadomienne dans les séries pré-sardes des Pyrénées Orientales: Approche géochimique, stratigraphique et géochronologique; Université de Lille 1: Lille, France, 2016; Available online: http: //ori-nuxeo.univ-lille1.fr/nuxeo/site/esupversions/38ae32e6-694a-470e-b34e-1b6938f8f6e8 (accessed on 28 January 2020).

28. Hartevelt, J.J.A. Geology of the upper Segre and Valira Valleys, Central Pyrenees, Andorra/Spain. Leidse Geol. Meded. 1970, 45, 167-236.

29. Laumonier, B.; Autran, A.; Barbey, P.; Cheilletz, A.; Baudin, T.; Cocherie, A.; Guerrot, C. Conséquences de l'absence de socle cadomien sur l'âge et la signification des séries pré-varisques (anté-Ordovicien supérieur) du sud de la France (Pyrénées, Montagne Noire). Bull. la Société Géologique Fr. 2004, 175, 643-655. [CrossRef]

30. Monod, B.; Regard, V.; Carcone, J.; Wyns, R.; Christophoul, F. Postorogenic planar palaeosurfaces of the central Pyrenees: Weathering and neotectonic records. Comptes Rendus Geosci. 2016, 348, 184-193. [CrossRef]

31. Ortuño, M.; Martí, A.; Martín-Closas, C.; Jiménez-Moreno, G.; Martinetto, E.; Santanach, P. Palaeoenvironments of the Late Miocene Prüedo Basin: implications for the uplift of the Central Pyrenees. J. Geol. Soc. 2013, 170, 79-92. [CrossRef]

32. Barrón, E.; Postigo-Mijarra, J.M.; Casas-Gallego, M. Late Miocene vegetation and climate of the La Cerdanya Basin (eastern Pyrenees, Spain). Rev. Palaeobot. Palynol. 2016, 235, 99-119. [CrossRef]

33. Fernandes, M.; Oliva, M.; Palma, P.; Ruiz-Fernández, J.; Lopes, L. Glacial stages and post-glacial environmental evolution in the Upper Garonne valley, Central Pyrenees. Sci. Total. Environ. 2017, 584, 1282-1299. [CrossRef]

34. Wilford, D.J.; Sakals, M.E.; Innes, J.L.; Sidle, R.C.; Bergerud, W.A. Recognition of debris flow, debris flood and flood hazard through watershed morphometrics. Landslides 2004, 1, 61-66. [CrossRef]

35. González, M.; Pinyol, J.; Camafort, M.; Vilaplana, J.; Oller, P. El mapa para la prevención de riesgos geológicos de cataluña 1:25 000: aplicación de una metodología a escala regional para la evaluación de la susceptibilidad a generar flujos torrenciales. In VIII Simposio sobre Taludes y Laderas Inestables; Alonso, E., Corominas, J., Hürlimann, M., Eds.; Centre Internacional de Màtodes Numèrics en Enginyeria (CIMNE): Barcelona, Spain, 2013; pp. 614-623.

36. Bosch i Pont, J.M. Evolució dels nuclis de població petits del Pallars Sobirà: Del 1850 a inicis del segle XXI. Ph.D. Thesis, Dpt. Geografia. Universitat de Barcelona, Barcelona, Spain, 2017. Available online: http://cataleg.ub.edu/record=b2244515 \{\}S1*cat (accessed on 26 June 2019).

37. Instituto Nacional de Estadística. Alteraciones de los municipios en los Censos de Población desde 1842; Instituto Nacional de Estadística: Madrid, Spain, 2017; Available online: http: //www.ine.es/intercensal/intercensal.do;jsessionid=14519F30BBA8257D11FF7EC9C3627D4C.intercensal02?

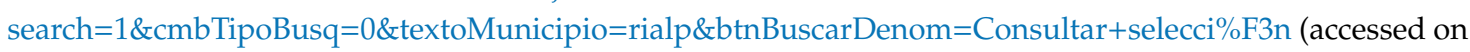
26 March 2018)Last revision 14 February 2017.

38. Walega, A.; Młyński, D.; Bogdał, A.; Kowalik, T. Analysis of the Course and Frequency of High Water Stages in Selected Catchments of the Upper Vistula Basin in the South of Poland. Water 2016, 8, 394. [CrossRef]

39. Arias, J.S. Máximas lluvias diarias en España Peninsular; Serie monografías; Ministerio de Fomento, Dirección General de Carreteras: Madrid, Spain, 1999; p. 54.

40. de Salas, L.; Carrero, L. MAXIN: Gis application to estimate Rainfall Intensity-Duration-Frequency laws in the Spanish peninsular área. In Proceedings of the 8th European Conference on Applications of Meteorology, Madrid, Spain, 13-17 September 2007.

41. De Salas, L.; Fernandez, J.A. "In-site" regionalization to estimate an intensity-duration-frequency law: a solution to scarce spatial data in Spain. Hydrol. Process. 2007, 21, 3507-3513. [CrossRef]

42. Trapero, L.; Bech, J.; Lorente, J. Numerical modelling of heavy precipitation events over Eastern Pyrenees: Analysis of orographic effects. Atmospheric Res. 2013, 123, 368-383. [CrossRef]

43. NRCS (Natural Resources Conservation Service). National Engineering Handbook. Part 630: Hydrology, chapter 9: Hydrologic soil-cover complexes; US Dept. of Agriculture: Washington, DC, USA, 2004.

44. NRCS (Natural Resources Conservation Service). National Engineering Handbook. Part 630: Hydrology, chapter 7: Hydrologic soil groups; US Dept. of Agriculture: Washington, DC, USA, 2007.

45. Te Chow, V.; Maidment, D.R.; Mays, L.W. Manual Hidrología Aplicada; McGraw-Hill: Bogotá, Colombia, 1994.

46. Fidelus-Orzechowska, J.; Wrońska-Wałach, D.; Cebulski, J.; Żelazny, M. Effect of the construction of ski runs on changes in relief in a mountain catchment (Inner Carpathians, Southern Poland). Sci. Total. Environ. 2018, 630, 1298-1308. [CrossRef] [PubMed] 
47. Ristić, R.; Kasanin-Grubin, M.; Radic, B.; Nikić, Z.; Vasiljevic, N. Land Degradation at the Stara Planina Ski Resort. Environ. Manag. 2012, 49, 580-592. [CrossRef] [PubMed]

48. Wrońska-Wałach, D.; Cebulski, J.; Fidelus-Orzechowska, J.; Żelazny, M.; Piątek, D. Impact of ski run construction on atypical channel head development. Sci. Total. Environ. 2019, 692, 791-805. [CrossRef] [PubMed]

49. Blöchl, G.; Ardoin-Bardin, S.; Bonell, M.; Dorninger, M.; Goodrich, D.; Gutknecht, D.; Matamoros, D.; Merz, B.; Shand, P.; Szolgay, J. At what scales do climate variability and land cover change impact on flooding and low flows? Hydrol. Process. 2007, 21, 1241-1247. [CrossRef]

50. Bovis, M.J.; Jakob, M. The role of debris supply conditions in predicting debris flow activity. Earth Surf. Process. Landforms 1999, 24, 1039-1054. [CrossRef]

51. Dearing, J. Landscape change and resilience theory: a palaeoenvironmental assessment from Yunnan, SW China. Holocene 2008, 18, 117-127. [CrossRef]

52. Corella, J.P.; Benito, G.; Rodriguez-Lloveras, X.; Brauer, A.; Valero-Garcés, B. Annually-resolved lake record of extreme hydro-meteorological events since AD 1347 in NE Iberian Peninsula. Quat. Sci. Rev. 2014, 93, 77-90. [CrossRef]

53. Ceola, S.; Botter, G.; Bertuzzo, E.; Porporato, A.; Rodriguez-Iturbe, I.; Rinaldo, A. Comparative study of ecohydrological streamflow probability distributions. Water Resour. Res. 2010, 46, W09502. [CrossRef]

54. Bodoque, J.M.; Diez-Herrero, A.; Eguibar, M.; Benito, G.; Ruiz-Villanueva, V.; Ballesteros-Cánovas, J. Challenges in paleoflood hydrology applied to risk analysis in mountainous watersheds - A review. J. Hydrol. 2015, 529, 449-467. [CrossRef]

55. Apollonio, C.; Balacco, G.; Novelli, A.; Tarantino, E.; Piccinni, A.F. Land Use Change Impact on Flooding Areas: The Case Study of Cervaro Basin (Italy). Sustain. 2016, 8, 996. [CrossRef]

56. Cunill, R.; Soriano, J.M.; Bal, M.C.; Pèlachs, A.; Rodriguez, J.M.; Pérez-Obiol, R.; Artigas, R.C. Holocene high-altitude vegetation dynamics in the Pyrenees: A pedoanthracology contribution to an interdisciplinary approach. Quat. Int. 2013, 289, 60-70. [CrossRef]

57. Lebourg, T.; Zerathe, S.; Fabre, R.; Giuliano, J.; Vidal, M. A Late Holocene deep-seated landslide in the northern French Pyrenees. Geomorphol. 2014, 208, 1-10. [CrossRef]

58. Abrantes, F.; Rodrigues, T.; Rufino, M.; Salgueiro, E.; Oliveira, D.; Gomes, S.; Oliveira, P.; Costa, A.; Mil-Homens, M.; Drago, T.; et al. The climate of the Common Era off the Iberian Peninsula. Clim. Past 2017, 13, 1901-1918. [CrossRef]

59. Llasat, M.-C.; Barriendos, M.; Barrera, A.; Rigo, T.; Barrera-Escoda, A. Floods in Catalonia (NE Spain) since the 14th century. Climatological and meteorological aspects from historical documentary sources and old instrumental records. J. Hydrol. 2005, 313, 32-47. [CrossRef]

60. Doblas-Miranda, E.; Alonso, R.; Arnan, X.; Bermejo, V.; Brotons, L.; Heras, J.D.L.; Estiarte, M.; Hódar, J.; Llorens, P.; Lloret, F.; et al. A review of the combination among global change factors in forests, shrublands and pastures of the Mediterranean Region: Beyond drought effects. Glob. Planet. Chang. 2017, 148, 42-54. [CrossRef]

61. Otsu, K.; Pla, M.; Brotons, L. Estimating the Severity of Defoliation Due to Pine Processionary Moth Using a Combination of Landsat and UAV Imagery. In Proceedings of the IGARSS 2018-2018 IEEE International Geoscience and Remote Sensing Symposium; Valencia, Spain, 22-27 July 2018, pp. 3979-3982. [CrossRef]

62. Füssel, H.-M. Climate change, impacts and vulnerability in Europe 2016-An indicator-based report; Publications Office of the European Union: Luxembourg, 2017; p. 419.

63. Pachauri, R.K.; Meyer, L.; Ypersele, J.P.V.; Brinkman, S.; Kesteren, L.V.; Leprince-Ringuet, N.; Boxmeer, F.V. Climate Change 2014 Synthesis Report The Core Writing Team Core Writing Team Technical Support Unit for the Synthesis Report. Russ. Fed. Hoesung Lee (Republic Korea) Scott. B. Power N.H. Ravindranath. Available online: https://www.ipcc.ch/pdf/assessment-report/ar5/syr/SYR_AR5_FINAL_full_wcover.pdf (accessed on 28 January 2020).

64. Segoni, S.; Piciullo, L.; Gariano, S.L. A review of the recent literature on rainfall thresholds for landslide occurrence. Landslides 2018, 15, 1483-1501. [CrossRef]

(C) 2020 by the authors. Licensee MDPI, Basel, Switzerland. This article is an open access article distributed under the terms and conditions of the Creative Commons Attribution (CC BY) license (http://creativecommons.org/licenses/by/4.0/). 